\title{
Politik İstikrarsızlık, Enerji Güvenliği ve Ekonomik Büyüme İlişkisi: Orta Doğu Ülkeleri Üzerine Ampirik Bir İnceleme*
}

\section{The Relationship between Political Instability, Energy Security and Economic Growth: An Empirical Analysis on the Middle Eastern Countries}

\author{
Gökhan Kartal ${ }^{\mathrm{a}, * *}$, Serdar Öztürk ${ }^{\mathrm{b}}$
}

a Dr., Niğde Ömer Halisdemir Üniversitesi, Niğde/Türkiye.

ORCID: 0000-0002-2006-6272

${ }^{\text {b }}$ Prof. Dr., Nevşehir Hacı Bektaş Veli Üniversitesi, İktisat Bölümü, Nevşehir/Türkiye.

ORCID: 0000-0003-0650-0244

\section{MAKALE BİLGISİ}

\section{Makale Geçmişi:}

Başvuru tarihi: 07 Ekim 2019

Düzeltme tarihi: 19 Haziran 2020

Kabul tarihi: 30 Haziran 2020

\section{Anahtar Kelimeler:}

Politik İstikrarsızlık

Enerji Güvenliği

Ekonomik Büyüme

Orta Doğu Ekonomileri

Panel Veri Analizi

Panel Eşbütünleşme

FMOLS

\section{ART ICLE INFO}

\section{Article history:}

Received 07 October 2019

Received in revised form 19 June 2020

Accepted 30 June 2020

\section{Keywords:}

Political Instability

Energy Security

Economic Growth

Middle East Economies

Panel Data Analysis

Panel Cointegration

FMOLS
ÖZ

Bu çalışmada, seçili 15 Orta Doğu ülkesinde 1996-2014 yılları arasında politik istikrarsızlık, enerji güvenliği ve ekonomik büyüme ilişkisinin incelenmesi amaçlanmıştır. Panel eşbütünleşme sonuçları değişkenler arasında uzun dönemli ilişkinin varlığını göstermektedir. Panel FMOLS sonuçlarına göre enerji güvenliği riskinde $\% 1$ artıș kiși baș GSYH'yi \%0,41 düşürürken, politik istikrardaki \%1 artış kişi başı GSYH'yi \%0,25 artırmaktadır. Tek Yönlü Sabit Zaman Etkili Panel EKK sonuçlarına göre enerji güvenliği riskinde \%1 artış kişi başı GSYH’yi \%0,62 düşürürken, politik istikrardaki \%1 artış kişi başı GSYH'yi \%0,35 artırmaktadır. Panel Granger Nedensellik sonuçları ise enerji güvenliği ile kişi başı GSYH arasında çift yönlü; enerji güvenliğinden politik istikrara ve kişi başı GSYH'den politik istikrara tek yönlü nedenselliği göstermektedir. Bu doğrultuda bu çalışmada enerji güvenliği ve politik istikrarın Orta Doğu ekonomilerinde önemli bir politika meselesi olduğu sonucuna varılmıştır.

\section{A B S T R A C T}

In this study, it is aimed to examine the relationship between political instability, energy security and economic growth between 1996-2014 in selected 15 Middle Eastern countries. Panel cointegration results show that there is long-term relationship between variables. According to the panel FMOLS results, while $1 \%$ increase in energy security risk decreases per capita GDP by $0.41 \%, 1 \%$ increase in political stability increases per capita GDP by $0.25 \%$. According to OneWay Fixed Effect Panel LS (based on period), while 1\% increase in energy security risk decreases per capita GDP by $0.62 \%, 1 \%$ increase in political stability increases per capita GDP by $0.35 \%$. The Panel Granger Causality results show that there is bi-directional causality relationship between energy security and GDP per capita, one-way causality relationship from energy security to political stability and from GDP per capita to political stability. Accordingly, in this study have been concluded that energy security and political stability are an important policy issue in the Middle Eastern economies.

\section{Giriş}

Birçok farklı tanımlama (bknz. Kartal, 2018: 4-6) yapılan politik istikrarsızlık kavramı, anayasal veya anayasaya aykırı araçlarla yürütme gücünde bir değişiklik eğilimidir

(Alesina ve Perotti, 1996: 191; Bellettini vd., 2013: 9). Literatürde yapılan tanımlamalardan yola çıkarak politik istikrarsızlık kavramı şu şekilde yeniden tanımlanabilir: Politik istikrarsızlık, politik sistemde sürekliliğin olmadığı,

\footnotetext{
* Bu çalışma birinci yazarın 2018 yılında Prof. Dr. Serdar Öztürk danışmanlığında Nevşehir Hacı Bektaş Veli Üniversitesi Sosyal Bilimler Enstitüsü İktisat Anabilim Dalı'nda yürüttüğ̈ “Orta Doğu Ülkelerinde Politik İstikrarsızlı, Enerji Güvenliği ve Ekonomik Büyüme İlişkisi” başlıklı doktora tezinden türetilmiştir.

** Sorumlu yazar/Corresponding author.

e-posta: gokhankartal.gk@gmail.com
} 
sosyo-politik gerginliklerden dolayı oluşan mülkiyet haklarını da içine alan toplumsal huzursuzluk ve şiddetin hakim olduğu belirsizlik halidir.

Politik istikrarsızlığın tanımında olduğu gibi, politik istikrarsızlık göstergeleri üzerinde de literatürde birçok farklı gruplandırmalar yapılmıştır. Genel olarak iki gruba indirgenebilecek politik istikrarsızlık göstergelerinden ilk gruplandırmaya göre politik istikrarsızlık iki ana başlık altında incelebilir. Birincisi yönetimsel istikrarsızlık, ikincisi ise toplumsal huzursuzluk ve siyasi şiddetin göstergelerine dayanmaktadır (bknz. Alesina ve Perotti, 1996: 1205; Bellettini vd., 2013: 19). İkinci gruplandırmaya göre ise politik istikrarsızlık yine iki ana başlıkta incelenmektedir. Birincisi düzenli ve düzensiz hükümet değişiklikleri (kabine değişiklikleri, anayasa değişiklikleri vb.) şeklindeki resmi istikrarsızlıklar; ikincisi devrimler, darbeler, iç savaşlar ve politik amaçlı suikastlar gibi daha sert yönlerini vurgulayan gayri resmi istikrarsızlıktır (Campos vd., 2012: 302; Campos ve Nugent, 2002: 159).

Konuyla ilgili literatür göz önüne alınarak politik istikrarsızlık göstergeleri; yönetimsel istikrarsızlık göstergeleri (resmi istikrarsızlık göstergeleri), toplumsal huzursuzluk ve politik şiddet göstergeleri (gayri resmi istikrarsızlık göstergeleri) ve kurumsal göstergeler olmak üzere üç ana başlıkta incelenebilir:

\section{A. Yönetimsel İstikrarsılılk Göstergeleri (Resmi} İstikrarsızlık Göstergeleri): Devlet başkanının değişmesi, seçim sayısı, parlamento değişiklikleri, kabine değişiklikleri (majör ve minör), hükümet krizleri, koalisyon ile kurulan hükümet sayısı, üst yönetim değişiklikleri, seçim sayısı, iktidardaki partinin yıl sayısı, rejim değişiklikleri, mecliste yer alan siyasi parti sayısı ve tasfiyelerdir.

B. Toplumsal Huzursuzluk ve Politik Şiddet Göstergeleri (Gayri Resmi İstikrarsızlık Göstergeleri): Politik bir amaca dayalı suikastlar, büyük ve küçük çaplı yurt içi şiddet olayları ve bu olaylarda öldürülen insan sayısı, başarılı ve başarısız darbeler, iç savaş, isyan, terör, grev, etnik çatışma ve kutuplaşma, dini gerginlikler ve bölünmedir.

C. Kurumsal Göstergeler: rejim, rejimin ömrü, bürokratik kalite, yolsuzluk, hukukun üstünlüğü, orta sınıfın boyutu, özel yatırımların kamulaştırılması ve sözleşmelerin reddedilmesi, bütçenin uygulanmasının esnekliği, yönetici istihdamında şeffaflık ve rekabet edebilirlik ve hukuki yapının kökenidir.

Politik istikrarsızlık, kendi kendisini besleyen bir kısır döngüyü de beraberinde getirmektedir. Aynı zamanda ekonomik büyümedeki düşüşlerde politik istikrarsızlığı besleyen bir diğer unsurdur. Alesina vd. (1996)'nin çalışmasında, politik istikrarsızlığın büyümeyi azalttığı, olası hükümet değişikliklerinin müteakip değişikliklerin olasılığını artırarak politik istikrarsızlığın kalıcı olma eğilimine sürüklediği ifade edilmiştir. Brückner ve Gradstein (2015), konuya ekonomik büyümenin politik riskleri azaltacağı şeklinde farklı bir açıdan bakarak gelir artışının politik riskleri azalttığını belirtmiştir. Ayrıca, etnik kutuplaşmanın az olduğu yerlerde gelir seviyesinin yüksek ve politik risklerin düşük olduğu sonucuna ulaşılmıştır.

Ekonomi ile ilgisi olmayan politik çatışmanın veya uluslararası siyasal gelişmelerin artmasından kaynaklanan bazı dışsal sebeplerden dolayı hükümetin çöküş ihtimalinin $\operatorname{arttığ1~bir~durumda,~şokun~bir~sonucu~olarak~yatırım~ve~}$ büyüme düşmekte ve böylece hükümetin çöküş ihtimali artarak politik belirsizliklerin daha da yoğunlaşmasına neden olmaktadır. Bu durum, politik istikrarsızlığın kendi kendini besleyen kısır döngüsüne örnektir. Öte yandan, büyümenin bazı dişsal sebeplerden dolayı düştüğü bir durumda halk, hükümeti (kısmen dahi olsa) kötü ekonomik sonuç için sorumlu tutacaktır. Bu, hükümetin çöküş ihtimalini artırarak büyümeyi daha da düşürecektir. Düşük büyüme, hükümetin istikrarsızlığını da artırmaktadır. Bu durum ise ekonomik büyümedeki düşüşün politik istikrarsızlığı beslemesi, yaşanan politik istikrarsızlığın büyümeyi daha da düşürmesi gibi bir kısır döngünün ortaya çıkmasına bir örnektir. Ampirik literatür, endüstriyel demokrasilerde görevdeki hükümetlerin yeniden seçilme şansının seçimlerden hemen önce büyüme oranına bağlı olduğunu göstermiştir. Demokratik olmayan ülkelerde düşük büyüme, popüler memnuniyetsizliği artırmakta, antihükümet faaliyetlerine yönelik teşvikler meydana getirerek darbeleri daha da olası kılmaktadır (Alesina vd., 1996: 191).

Şekil 1. Politik İstikrarsızlığın Kısır Döngüsü

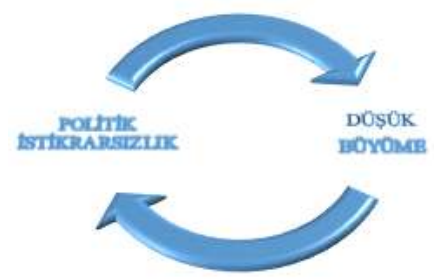

Enerji ise modern dünya ekonomisinin işleyişinde merkezi bir önem taşımaktadır. Sacko (2004)'e göre enerji, ekonomik büyümenin önemli bir kaynağı olup, enerji kullanımındaki artış ekonomik büyümeyi etkilemektedir. Çünkü enerji, birçok tüketim ve üretim faaliyeti için temel üretim faktörüdür. Fiziksel açıdan enerji kullanımında artış ekonomik üretkenliğe ve endüstriyel büyümeye yol açar. $\mathrm{Bu}$ teori, 1973 petrol şokundan önceki yılların gözlemleriyle desteklenen birim elastikiyete dayanmaktadır. İlk petrol şokuna (1973-1974) kadar, OECD ülkelerindeki ortalama esneklik katsayısı 1'dir. Yani \%1'lik enerji tüketimindeki artış, \%1'lik GSYH artışı meydana getirmektedir. Fakat 1974-1975'ten ve özellikle 1979'dan bu yana, bu ülkelerde GSYH birimi başına enerji tüketimi azalmıştır. $\mathrm{Bu}$ durumun sebebi enerji verimliliğinden kaynaklanan gelişmeler olup, enerji tüketiminde \%1'lik artış GSYH'de \%1'den daha fazla artışa olanak sağlamıştır. Barney ve Franzi (2002), modern ekonomide endüstriyel büyümenin en az yarısının enerji kaynaklı olduğunu ve üretim maliyetinin onda birinden fazlasını enerjinin temsil ettiğini iddia etmektedir (Saidi vd., 2017: 46). Hatta Voser (2012) enerjiyi ekonominin oksijeni ve büyümenin can damarı olarak tanımlamaktadır. Gerçekten de günümüz ülkelerinin ekonomik yapılarına bakıldığında, bazı ülkelerin doğrudan enerji üretimi sonucunda elde ettiği gelirlerin ülke GSYH'lerinde önemli yeri olduğu görülürken, bazı ülkelerde ise üretim aşamasında enerjiyi önemli bir girdi olarak kullanarak enerjinin katma değerini $\operatorname{artırdığ~}$, bu yolla da yüksek GSYH değerlerine ulaştı̆̆ı görülmektedir. Stern (1993), emek ve sermayeden oluşan üretim fonksiyonuna enerjiyi de ekleyerek enerjiyi bir üretim fonksiyonu olarak ele almıştır (Karagöl vd., 2007: 73). 
Enerji tüketimi ekonomik büyümeyi artırmasının yanında yaşam standartlarını da geliştirir. İnsan yaşamını kolaylaştıran birçok teknolojik cihazın hem üretim aşamasında hem de bu cihazların kullanımında yoğun bir şekilde enerjiden yararlanılmaktadır. Enerji tüketimindeki artışın ekonomik büyümeyi artırmasının yanında, ekonomik büyümedeki artışında enerji tüketimini artırdığını belirtmek gerekir.

Enerjinin var olan önemi, enerjiye erişileme durumunu modern dünya ekonomisinin kâbusu haline getirerek enerji güvenliği kavramını ortaya çıkarmıştır. IEA'ya (International Energy Agency-Uluslararası Enerji Ajans1) göre enerji güvenliği "uygun fiyatta kesintisiz enerji kaynakları bulunabilirliği" olarak tanımlamaktadır (IEA, 2017). Enerji güvenliği, kesintisiz bir enerji arzının bir ekonominin işleyişi için kritik olduğu fikrine dayanmakta, geleneksel olarak, petrol kaynaklarına erişimin korunması ve yaklaşmakta olan fosil yakıt tükenmesi ile ilişkilendirilmektedir (Kruyt vd., 2009: 2167). Kısaca enerji güvenliği "enerjinin makul bir fiyatla güvenilir ve yeterli miktarda arzı" ya da "ekonomik büyüme ve performansın devamlılığının sağlanması için yeterli miktarda enerji arzının makul ve istikrarlı fiyatlarla sağlanması" şeklinde tanımlanabilir (Çelikpala, 2014: 85). Yeterli miktarda enerji kaynağına ulaşabilme yeteneği, makul fiyatlarla enerji alımı, ulaşılabilirlik ve maliyet unsurlarının yakın ve orta vadeli gelecekte öngörülebilir olması, enerji alımıyla ilgili risklerin minimize edilmesi, geçiş ülkelerinin istikrarı, kullanılan enerji kaynaklarının çeşitlendirilmesi ve özellikle yenilenebilir enerji kaynaklarına yönelmek, bağımlılığı azaltmak adına ithalat yapılan ülkelerin çeşitlendirilmesi, ülke içinde enerji verimliğinin yükseltilmesi, enerji alanındaki yatırımların teşvik edilmesi ve son olarak enerji güvenliği ile çevre güvenliğinin beraber düşülmesi enerji güvenliği tanımını şekillendiren ana unsurlardır (Karabulut, 2017: 34).

BP (2017)'ye göre Orta Doğu bölgesi verileri incelendiğinde 2016 yılı itibariyle Orta Doğu bölgesi petrolde 877,93 milyar varil ile dünya petrol rezervlerinin \%51,44'üne sahip olduğu görülmektedir. Petrol üretiminde ise $1.622,19$ milyon ton ile dünya toplam petrol üretiminin \%37,02'sini gerçekleştirmektedir. Doğalgaz açısından da zengin olan bölge 87,23 trilyon metreküp ile dünya doğalgaz rezervlerinin $\% 46,75$ 'ine sahiptir. Üretimde ise 781,01 milyar metreküp ile dünya üretiminin \%21,99'unu gerçekleştirmektedir. Bunun yanında bölge, petrol taşımacılığında stratejik önemdeki (Süveyş Kanalı, Bal El Mandab, Hürmüz Boğazı, Basra Körfezi gibi) bölge ve geçiş güzergâhlarına sahiptir. Ayrıca BP (2017)'de petrol ticaretinde önemli paya sahip olan bölgeler ve ülkelerin verileri incelendiğinde, Orta Doğu'nun dünya ham petrol ticaretinin \%46,39'una hakim olduğu görülmektedir. BP (2017) verilerine ülkeler açısından bakıldığında Suudi Arabistan ham petrol ihracatında yıllık 375,32 milyon ton ve $\% 17,7^{\prime}$ lik pay ile dünyada ilk sırada yer almaktadır. Suudi Arabistan ile birlikte Irak, Kuveyt ve BAE'nin yer aldığı 4 ülkenin dünya ham petrol ihracatının \%36,8'ini gerçekleştirdikleri görülmektedir. Ayrıca, bölge ülkelerinin petrol ve doğalgazdan elde edilen gelirlerin GSYH ve ihracat gelirlerindeki payları bölgedeki çoğu ülkede yüksek oranlarda olduğu görülmektedir. Orta Doğu'nun dünyanın en önemli enerji kaynaklarına sahip olmasının yanı sıra önemli geçiş noktalarının bu bölgede bulunması ve Bölge ekonomilerinin enerji kaynaklarından elde edilen gelirlere aşırı bağımlılığı, enerji güvenliği ile büyüme ilişkisinin incelendiği bu çalışmada, Orta Doğu ülkelerinin seçilmesinin en temel sebebini oluşturmaktadır. Bunun yanında, Orta Doğu politik istikrarsızlık olayları açısından dünyanın en istikrarsız bölgelerinden birisidir. $\mathrm{Bu}$ bağlamda, tarihsel süreç içinde yaşanan Arap-İsrail Savaşları, Lübnan İç Savaşı, İran Devrimi, İran-Irak Savaşı, Birinci ve İkinci Körfez Savaşı, Birinci ve İkinci İntifada, Irak'ın İşgali ve etkisi halen devam eden Arap Baharı olaylarının yanı sıra birçok darbe, devrim, iç savaş, suikast gibi çok sayıda politik istikrarsızlık olayının yaşandığı bir bölgedir. Bu anlamda bu olayların hem bölge hem de dünya enerji güvenliğini tehdit etmesinin yanı sıra diğer ekonomik değişkenlere de doğrudan olumsuz etkisi söz konusudur. Literatürde konu ile ilgili çok az sayıda çalışma olması bu çalışmanın önemini artıran en önemli husus olup, bu bağlamda bu çalışmayla literatüre önemli bir katkı sağlanması hedeflenmiştir. $\mathrm{Bu}$ amaçla bu çalışmada öncelikle enerji güvenliği, politik istikrarsızlık ve ekonomik büyüme temelinde ilgili literatür incelenecektir. Sonraki bölümde bu çalışmada kullanılan veri seti ve metodoloji tanitılacaktır. Son bölümde ise ekonometrik analizden elde edilen sonuçlar tablolaştırılarak değerlendirilecektir.

\section{Literatür Özeti}

Politik istikrarsızlıkların ekonomik büyüme, özel yatırım, vergilendirme, kamu harcamaları ve yatırım, borç ve enflasyon da dahil olmak üzere çok çeşitli makroekonomik değişkenler üzerindeki olumsuz etkilerini belgeleyen geniş bir literatür ortaya çıkmıştır (Aisen ve Veiga, 2013: 151). $\mathrm{Bu}$ geniş literatür (bknz. Tablo $1^{1}$ ) ekonomik büyümenin doğrudan veya dolaylı belirleyicilerini kapsamakta, politik istikrarsızlığın ekonomik büyümedeki etkisini göstermektedir.

\footnotetext{
${ }^{1} \mathrm{Bu}$ çalışmada yer alan literatür özetinde doğrudan ekonomik büyümeye ilişkin literatüre yer verilmiş olup, politik istikrarsızlığın diğer ekonomik değişkenler üzerine etkisini de kapsayan geniş literatür için bknz. Kartal, 2018: 242-246; Kartal, 2020: 48-57.
} 
Tablo 1. Politik İstikrarsızlık Ekonomik Büyüme Literatür Özeti

\begin{tabular}{|c|c|c|c|c|c|}
\hline $\mathbf{S}$ & Yazar & Konu & Dönem & Ülke & Sonuç \\
\hline 1 & $\begin{array}{l}\text { Aisen ve Veiga } \\
(2013)\end{array}$ & $\begin{array}{l}\text { Politik istikrarsızlık ve diğer } \\
\text { politik ve kurumsal değişkenlerin } \\
\text { ekonomik büyümeye etkisi }\end{array}$ & $\begin{array}{l}1960- \\
2004\end{array}$ & 169 ülke & $\begin{array}{l}\text { Politik istikrarsılığın büyümeye etkisi negatiftir. } \\
\text { Demokrasinin küçük de olsa büyümeye etkisi negatiftir. }\end{array}$ \\
\hline 3 & $\begin{array}{l}\text { Alesina } \quad \text { vd. } \\
(1996)\end{array}$ & $\begin{array}{l}\text { Politik istikrarsızlık ile kişi başı } \\
\text { GSYH büyümesi arasındaki ilişki }\end{array}$ & $\begin{array}{c}1950- \\
1982\end{array}$ & 113 ülke & Politik istikrarsızlık büyümeyi azaltmaktadır. \\
\hline 4 & $\begin{array}{l}\text { Alesina ve } \\
\text { Perotti (1996) }\end{array}$ & Sosyo-politik istikrarsızlık & $\begin{array}{c}1960- \\
1985\end{array}$ & 71 ülke & $\begin{array}{l}\text { SPI hem gelir düzeyi hem de eğitim düzeyi ile negatif yönde } \\
\text { ilişkilidir. }\end{array}$ \\
\hline 5 & Alper (2018) & $\begin{array}{l}\text { Politik istikrarın } \\
\text { büyüme üzerine etkisi }\end{array}$ & $\begin{array}{l}1996- \\
2016 \\
\end{array}$ & BRICS-T & $\begin{array}{l}\text { Politik istikrardaki \%1'lik artış ekonomik büyümeyi \%1.27 } \\
\text { arttırmaktadır. }\end{array}$ \\
\hline 6 & $\begin{array}{l}\text { Bellettini vd. } \\
(2013)\end{array}$ & $\begin{array}{lr}\text { Siyasi } & \text { kalıcılık/ } \\
\text { devamlılık/süreklilik } & \text { ile } \\
\text { ekonomik büyüme } & \text { arasındaki } \\
\text { ilişki } & \end{array}$ & $\begin{array}{l}1984- \\
2008\end{array}$ & 62 ülke & $\begin{array}{l}\text { Siyasi kalıcılık/devamlılık/süreklilik ile ekonomik büyüme } \\
\text { arasındaki ilişki negatiftir. }\end{array}$ \\
\hline 7 & $\begin{array}{l}\text { Brückner ve } \\
\text { Gradstein } \\
(2015)\end{array}$ & $\begin{array}{l}\text { Ülkelerin ulusal gelirlerindeki } \\
\text { büyümenin siyasi risk üzerindeki } \\
\text { etkileri }\end{array}$ & $\begin{array}{l}1984- \\
2007\end{array}$ & $\begin{array}{l}115 \text { 'den fazla } \\
\text { ülke }\end{array}$ & $\begin{array}{l}\text { Kişi başı GSYH büyümesindeki bir puanlık artış, siyasi risk } \\
\text { endeksini yaklaşık } 0,1 \text { puan azaltmaktadır. }\end{array}$ \\
\hline 8 & $\begin{array}{l}\text { Butkiewicz ve } \\
\text { Yanikkaya } \\
(2005)\end{array}$ & $\begin{array}{l}\text { Sosyo-politik istikrarsızlık, } \\
\text { demokrasi ve gelir ilişkisi }\end{array}$ & $\begin{array}{l}1970- \\
1997\end{array}$ & $\begin{array}{l}\text { 100'den fazla } \\
\text { gelişmekte } \\
\text { olan ülke } \\
\end{array}$ & $\begin{array}{l}\text { Sosyo-politik istikrarsızlık geliri olumsuz etkilemektedir. } \\
\text { Fakat demokrasi seviyesine bağlı olarak etki gücü farklıdır. }\end{array}$ \\
\hline 9 & $\begin{array}{l}\text { Campos ve } \\
\text { Karanasos } \\
(2008)\end{array}$ & $\begin{array}{l}\text { Ekonomik büyüme, dalgalanma } \\
\text { ve politik istikrarsızlık ilişkisi }\end{array}$ & $\begin{array}{l}1896- \\
2000\end{array}$ & Arjantin & $\begin{array}{llll}\text { "Gayri resmi" politik istikrarsızlık doğrudan, "resmi” } \\
\begin{array}{l}\text { istikrarsızlık } \\
\text { etkilemektedir. }\end{array} & & & \\
\text { dolaylı olarak büyümeyi } & \text { olumsuz } \\
\end{array}$ \\
\hline 10 & $\begin{array}{l}\text { Campos ve } \\
\text { Nugent (2002) }\end{array}$ & $\begin{array}{l}\text { SPI ile ekonomik büyüme } \\
\text { arasındaki nedensellik }\end{array}$ & $\begin{array}{c}1960- \\
1995\end{array}$ & $\begin{array}{l}\text { Gelişmekte } \\
\text { olan } 98 \text { ülke }\end{array}$ & $\begin{array}{l}\text { Siyasi istikrarsızlıktan ekonomik büyüme doğru nedensellik } \\
\text { ve negatif ilişki olmakla birlikte, uzun vadeli ilişki } \\
\text { bulunmamıştır. }\end{array}$ \\
\hline 11 & $\begin{array}{l}\text { Campos vd. } \\
(2012)\end{array}$ & $\begin{array}{l}\text { Politik istikrarsızlık, ekonomik } \\
\text { büyüme ve finansal gelişme }\end{array}$ & $\begin{array}{l}1896- \\
2000\end{array}$ & Arjantin & $\begin{array}{l}\text { Politik istikrarsızlık, ekonomik büyüme ve finansal gelişme } \\
\text { üzerinde olumsuz etkiye sahiptir. }\end{array}$ \\
\hline 12 & $\begin{array}{l}\text { Caporalea ve } \\
\text { Leirer }(2010)\end{array}$ & $\begin{array}{l}\text { Politik istikrarsızlık ile ekonomik } \\
\text { büyüme ilişkisi }\end{array}$ & $\begin{array}{l}1975- \\
2005\end{array}$ & $\begin{array}{c}50 \mathrm{ABD} \\
\text { eyaleti }\end{array}$ & Politik istikrarsızlık ekonomik büyüme etkisi negatiftir. \\
\hline 13 & $\begin{array}{l}\text { Chen ve Feng } \\
(1996)\end{array}$ & $\begin{array}{l}\text { Siyasi çevrenin ekonomik } \\
\text { büyüme üzerindeki etkileri }\end{array}$ & $\begin{array}{c}1974- \\
1990\end{array}$ & $\begin{array}{l}7 \text { OECD } \\
\text { ülkesi }\end{array}$ & $\begin{array}{l}\text { Rejim istikrarsızlığı, politik kutuplaşma ve hükümet baskısı } \\
\text { büyüme üzerinde negatif bir etkiye sahiptir. }\end{array}$ \\
\hline 14 & Fosu $(2001)$ & $\begin{array}{l}\text { Siyasi istikrarsızlık ve ekonomik } \\
\text { büyüme arasındaki ilişki }\end{array}$ & $\begin{array}{c}1960- \\
1986\end{array}$ & $\begin{array}{l}\text { Sahraaltı } \\
\text { Afrika }\end{array}$ & $\begin{array}{l}\text { Çeşitli siyasi istikrarsızlık olaylarının başlıca bileşenlerinin } \\
\text { arttırılmış bir üretim fonksiyonunda uygulandığında, temel } \\
\text { spesifikasyon testlerine (Specification-Based Testing) } \\
\text { uyulduğunu tespit edilmiştir. }\end{array}$ \\
\hline 15 & $\begin{array}{l}\text { Gurgul ve Lach } \\
(2013)\end{array}$ & $\begin{array}{l}\text { Ekonomik büyüme ile politik } \\
\text { istikrarsızlık ilişkisi }\end{array}$ & $\begin{array}{l}1990- \\
2009\end{array}$ & $\begin{array}{l}10 \mathrm{CCE} \\
\text { ülkesi }\end{array}$ & $\begin{array}{l}\text { Hükümet değişikliği eğilimi olarak tanımlanan siyasi } \\
\text { istikrarsızlığın büyüme üzerinde olumsuz bir etkisi olduğu } \\
\text { bulunmuştur. Buna karşın büyümeden politik istikrara doğru } \\
\text { bir nedensellik bulunamamıştır. }\end{array}$ \\
\hline 16 & $\begin{array}{l}\text { Jong-A-Pin } \\
(2009)\end{array}$ & $\begin{array}{l}\text { Politik istikrarsızlık ile ekonomik } \\
\text { büyüme ilişkisi }\end{array}$ & $\begin{array}{c}1974- \\
2003 \text { ve } \\
1984- \\
2003\end{array}$ & - & $\begin{array}{l}\text { Politik rejimin istikrarsılı̆ğı, ekonomik büyüme üzerinde } \\
\text { sağlam ve önemli bir negatif etkiye sahiptir. }\end{array}$ \\
\hline 17 & $\begin{array}{l}\text { Kartal ve } \\
\text { Öztürk (2018) }\end{array}$ & $\begin{array}{l}\text { Politik istikrasızlık, uluslararası } \\
\text { göç hareketleri ve ekonomik } \\
\text { büyüme arasındaki ilişki }\end{array}$ & $\begin{array}{l}1996- \\
2016\end{array}$ & $\begin{array}{l}\text { Türkiye, İran, } \\
\text { Irak ve Suriye }\end{array}$ & $\begin{array}{l}\text { Göçmen girişi ve politik istikradaki \%1'lik artış ekonomik } \\
\text { büyümeyi sırasıyla \% } 0,022 \text { ve } \% 0,984 \text { artırmakta; göçmen } \\
\text { olarak ülkeden çıkş̧taki \%1'lik artış ekonomik büyümeyi \% } \\
0,488 \text { azaltmaktadır. }\end{array}$ \\
\hline 18 & $\begin{array}{l}\text { Klomp ve Haan } \\
(2009)\end{array}$ & $\begin{array}{lrr}\begin{array}{l}\text { Siyasi } \\
\text { büyüme } \\
\text { etkisi }\end{array} & \text { volatilitesi } & \begin{array}{r}\text { ekonomik } \\
\text { üzerindeki }\end{array} \\
\end{array}$ & $\begin{array}{l}1960- \\
2005\end{array}$ & 112 ülke & $\begin{array}{l}\text { Demokrasi ekonomik volatiliteyi azaltmakta, politik } \\
\text { istikrarsızlık ve politika belirsizlikleri ekonomik volatiliteyi } \\
\text { artırmaktadır. }\end{array}$ \\
\hline 19 & Knutsen (2013) & $\begin{array}{l}\text { Devlet kapasitesinin ekonomik } \\
\text { büyümedeki rolü }\end{array}$ & $\begin{array}{l}1984- \\
2004\end{array}$ & $\begin{array}{l}\text { Sahraltı } \\
\text { Afrika }\end{array}$ & $\begin{array}{l}\text { Demokrasinin büyüme üzerinde etkisi güçlü ve pozitif } \\
\text { olarak bulunmuştur. }\end{array}$ \\
\hline 20 & Man (2016) & $\begin{array}{llc}\text { Siyasi } & \text { rekabet } & \text { bileşenleri } \\
\text { (yürütme ve yasama } & \text { organı) ve } \\
\text { ekonomik büyüme } & \text { arasındaki } \\
\text { ilişki } & & \\
\end{array}$ & $\begin{array}{l}1975- \\
2007\end{array}$ & 187 ülke & $\begin{array}{l}\text { Siyasi rekabet (genel ve yürütme açısından) ile büyüme } \\
\text { arasında U şeklinde doğrusal olmayan bir ilişkinin varlığı } \\
\text { tespit edilmiştir. }\end{array}$ \\
\hline 21 & $\begin{array}{l}\text { Martin ve } \\
\text { Rogers (2000) }\end{array}$ & $\begin{array}{l}\text { Büyüme ile ekonomik } \\
\text { istikrarsızlık arasındaki ilişki }\end{array}$ & $\begin{array}{c}1979- \\
1992 \text { ve } \\
1960- \\
1988\end{array}$ & 97 ülke & $\begin{array}{l}\text { Politik istikrarsızlık ekonomik istikrarsızlıkta önemli bir } \\
\text { etkendir. }\end{array}$ \\
\hline 22 & $\begin{array}{l}\text { Menegaki ve } \\
\text { Ozturk (2013) }\end{array}$ & $\begin{array}{l}\text { Ekonomik büyüme ile politik } \\
\text { istikrar dahil olmak üzere bazı } \\
\text { değişkenlerle ilişsisi }\end{array}$ & $\begin{array}{l}1975- \\
2009\end{array}$ & $\begin{array}{l}26 \text { Avrupa } \\
\text { ülkesi }\end{array}$ & $\begin{array}{l}\text { Büyüme ve politik istikrar, sermaye ve politik istikrarsılık, } \\
\text { sermaye ve fosil enerji tüketimi arasındaki iki yönlü } \\
\text { nedensellik vardır. }\end{array}$ \\
\hline 23 & $\begin{array}{l}\text { Miljkovic ve } \\
\text { Rimal (2008) }\end{array}$ & $\begin{array}{l}\text { Politik istikrarsızlık ile ekonomik } \\
\text { büyüme ilişkisi }\end{array}$ & $\begin{array}{c}1960- \\
1988\end{array}$ & 122 ülke & $\begin{array}{l}\text { Gelir artış hızı, ilk gelir düzeyi ve politik rejimin doğası gibi } \\
\text { çeşitli sosyo-ekonomik faktörlerin politik istikrarı etkilediği } \\
\text { hipotezini doğrulamıştır. }\end{array}$ \\
\hline 24 & $\begin{array}{l}\text { Özer } \\
\text { Kocaman } \\
(2019)\end{array}$ & $\begin{array}{l}\text { Politik istikrarsızlık } r \text { ve } \\
\text { makroekonomik değişkenler } \\
\text { (büyüme, enflasyon ve döviz } \\
\text { kuru) arasındaki nedensellik } \\
\text { ilişkisi }\end{array}$ & $\begin{array}{l}1992- \\
2016\end{array}$ & $\begin{array}{l}\text { Türkiye, } \\
\text { Hindistan, } \\
\text { Rusya, } \\
\text { Meksika ve } \\
\text { Endonezya }\end{array}$ & $\begin{array}{l}\text { Politik istikrarsızlık ile bazı makroekonomik değişkenler } \\
\text { arasında nedensellik ilişkisinin kanıtları bulunmuştur. }\end{array}$ \\
\hline
\end{tabular}




\begin{tabular}{|c|c|c|c|c|c|}
\hline $\mathbf{S}$ & Yazar & Konu & Dönem & Ülke & Sonuç \\
\hline 25 & $\begin{array}{l}\text { Rachdi ve Saidi } \\
\text { (2015) }\end{array}$ & $\begin{array}{l}\text { Demokrasi ile ekonomik büyüme } \\
\text { ilişsisi }\end{array}$ & $\begin{array}{l}1983- \\
2012\end{array}$ & $\begin{array}{l}\text { MENA } \\
\text { ülkeleri }\end{array}$ & $\begin{array}{l}\text { Demokrasi MENA ülkelerinde büyüme üzerinde sağlam ve } \\
\text { olumsuz bir etkiye sahiptir. }\end{array}$ \\
\hline 26 & Radu (2015) & $\begin{array}{l}\text { Politik istikrarın ekonomik } \\
\text { büyüme üzerindeki etkisi }\end{array}$ & $\begin{array}{l}1990- \\
2011\end{array}$ & Romanya & $\begin{array}{l}\text { Politik istikrarın ekonomik büyüme üzerindeki etkisi } \\
\text { pozitiftir. }\end{array}$ \\
\hline 27 & Şanlısoy (2020) & $\begin{array}{l}\text { Politik istikrarsıllık ile ekonomik } \\
\text { büyüme arasındaki nedensellik } \\
\text { ilişkisi }\end{array}$ & $\begin{array}{l}1987- \\
2015\end{array}$ & Türkiye & $\begin{array}{l}\text { Ekonomik büyümede meydana gelen pozitif şokların politik } \\
\text { istikrarsızlk üzerinde pozitif şoklara neden olmaktadır. }\end{array}$ \\
\hline 28 & $\begin{array}{l}\text { Şanlısoy ve } \\
\text { Çetin (2017) }\end{array}$ & $\begin{array}{llr}\text { Politik } & \text { istikrarsılık } & \text { ile } \\
\text { makroekonomik } & \text { performans } \\
\text { değişkeni } & \text { arasındaki } & \text { nedensellik } \\
\text { ilişsisi } & & \end{array}$ & $\begin{array}{l}1984- \\
2015\end{array}$ & Türkiye & $\begin{array}{l}\text { Politik istikrarsılıktan makroekonomik performansa doğru } \\
\text { bir nedensellik vardır. }\end{array}$ \\
\hline 29 & $\begin{array}{l}\text { Şanlısoy ve Kök } \\
\text { (2016) }\end{array}$ & $\begin{array}{l}\text { Politik istikrasızlık ve ekonomik } \\
\text { büyüme }\end{array}$ & $\begin{array}{l}1987- \\
2006\end{array}$ & Türkiye & $\begin{array}{l}\text { Politik istikrasızlıkla ekonomik büyüme arasındaki ters } \\
\text { yönlü ilişki }\end{array}$ \\
\hline 30 & Sen (2013) & $\begin{array}{l}\text { Kurumsal kalite ile ekonomik } \\
\text { büyüme arasındaki ilişsi }\end{array}$ & $\begin{array}{l}1984- \\
2010\end{array}$ & 110 ülke & $\begin{array}{l}\text { Kurumsal kalite ekonomik büyümenin devam etmesi } \\
\text { açısından önemlidir. }\end{array}$ \\
\hline 31 & Sweidan (2016) & $\begin{array}{l}\text { Politik istikrasızlık ve ekonomik } \\
\text { büyüme }\end{array}$ & $\begin{array}{l}1967- \\
2009\end{array}$ & Ürdün & $\begin{array}{l}\text { Politik istikrarsızlı̆ı̆ ekonomik büyüme ve reel devlet } \\
\text { harcamaları üzerinde istatistiksel olarak anlamlı bir olumsuz } \\
\text { etkisi vardır. }\end{array}$ \\
\hline 32 & $\begin{array}{l}\text { Tabassam } \\
(2016)\end{array}$ & $\begin{array}{l}\text { Politik istikrarsılılık ve ekonomik } \\
\text { büyüme ilişkisi }\end{array}$ & $\begin{array}{l}1988- \\
2010\end{array}$ & Pakistan & $\begin{array}{l}\text { Siyasi istikrarsızlı̆ı̆ı ekonomik büyüme üzerinde belirgin } \\
\text { bir olumsuz etkisi }\end{array}$ \\
\hline 33 & $\begin{array}{l}\text { Tang } \\
\text { Abosedra } \\
(2014)\end{array}$ & $\begin{array}{ll}\text { Turizm, enerji } & \text { tüketimi, politik } \\
\text { istikrarsizlık } & \text { ve ekonomik } \\
\text { büyüme } & \end{array}$ & $\begin{array}{l}2001- \\
2009\end{array}$ & $\begin{array}{l}24 \text { MENA } \\
\text { ülkesi }\end{array}$ & $\begin{array}{l}\text { Siyasi istikrarsızlık MENA bölgesindeki ekonomik büyüme } \\
\text { ve gelişme sürecini de engellemektedir. }\end{array}$ \\
\hline 34 & $\begin{array}{l}\text { Toledo ve } \\
\text { Venieris (2014) }\end{array}$ & $\begin{array}{l}\text { Sosyo-politik } \begin{array}{r}\text { istikrarsızlık } \\
\text { endeksi ile ekonomik büyüme } \\
\text { ilişkisi }\end{array} \\
\end{array}$ & $\begin{array}{l}1980- \\
2000\end{array}$ & 62 ülke & $\begin{array}{l}\text { Sosyo-politik istikrarsızlık endeksi ile büyüme arasında } \\
\text { negatif ilişkili vardır. }\end{array}$ \\
\hline 35 & $\begin{array}{l}\text { Yalçınkaya ve } \\
\text { Kaya (2017) }\end{array}$ & $\begin{array}{l}\text { Politik istikrasızlık ile ekonomik } \\
\text { büyüme arasındaki ilişki }\end{array}$ & $\begin{array}{l}1996- \\
2015\end{array}$ & $\begin{array}{l}\text { Gelişmiş G- } \\
12 \text { ve } \\
\text { gelişmekte } \\
\text { olan G-8 } \\
\text { ülkeleri }\end{array}$ & $\begin{array}{l}\text { G-12 ve G- } 8 \text { gruplarında politik istikrar/istikrarsızlık } \\
\text { endeksinin ekonomik büyüme üzerindeki etkileri } \\
\text { pozitif/negatif yönlü olup, sonuçlar istatistiki açıdan } \\
\text { anlamlıdır. }\end{array}$ \\
\hline 36 & Yang (2011) & $\begin{array}{lrr}\text { Siyasi ve } & \text { ekonomik } \\
\text { liberalizasyonun } & \text { büyüme } \\
\text { volatilitesi üzerindeki etkileri }\end{array}$ & $\begin{array}{l}1970- \\
2005\end{array}$ & 158 ülke & $\begin{array}{l}\text { Demokratikleşmenin daha hızlı büyümeye neden olduğuna } \\
\text { yönelik kesin kanıt bulunamamıştır. }\end{array}$ \\
\hline 37 & $\begin{array}{l}\text { Younis } \\
\text { (2008) }\end{array}$ & $\begin{array}{l}\text { Politik istikrarsızlığın büyüme ile } \\
\text { ilgili değişkenler üzerindeki etkisi }\end{array}$ & $\begin{array}{l}1990- \\
2005\end{array}$ & $\begin{array}{l}\text { 10 Asya } \\
\text { ülkesi }\end{array}$ & $\begin{array}{l}\text { Politik istikrar ekonomik büyümenin belirleyicileri üzerinde } \\
\text { doğrudan ve dolaylı etkiye sahiptir. }\end{array}$ \\
\hline 38 & $\begin{array}{ll}\text { Zouhaier } & \text { ve } \\
\text { Kefi (2012) } & \\
\end{array}$ & $\begin{array}{l}\text { Politik istikrasızlık-yatırım- } \\
\text { büyüme arasındaki ilişki }\end{array}$ & $\begin{array}{l}2000- \\
2009\end{array}$ & $\begin{array}{l}\text { 11 MENA } \\
\text { ülkesi }\end{array}$ & $\begin{array}{l}\begin{array}{l}\text { Politik istikrarsızlı̆ın yatırım ve ekonomik büyüme } \\
\text { üzerinde etkisi yoktur. }\end{array} \\
\end{array}$ \\
\hline $\begin{array}{l}\text { Bu } \\
\text { güver } \\
\text { istikr } \\
\text { güver } \\
\text { denec } \\
\text { enerj }\end{array}$ & $\begin{array}{l}\text { çalışmada, pol } \\
\text { aliği de anal } \\
\text { arsızlığın aksin } \\
\text { aliği arasındaki } \\
\text { ek kadar az say } \\
\text { konusu çok }\end{array}$ & $\begin{array}{l}\text { ik istikrarsızlığın yanınd } \\
\text { ze dahil edilmiş olup, }\end{array}$ & $\begin{array}{r}\text { enerji } \\
\text { politik } \\
\text { enerji } \\
\text { lar yok } \\
\text { türünde } \\
\text { ampirik }\end{array}$ & \multicolumn{2}{|c|}{$\begin{array}{l}\text { ülkesi için New Energy Security Index (NSI) } \\
\text { oluşturmuştur. CPI'nın bağımlı değişken olduğu modelde } \\
\text { enerji güvenliğindeki artış ile enflasyon arasında negatif } \\
\text { ilişki bulunurken; GDP'nin bağımlı olduğu modelde enerji } \\
\text { güvenliğindeki artışların GSYH'yı pozitif etkilediği } \\
\text { sonucuna varılmıştır. }\end{array}$} \\
\hline
\end{tabular}
çalışmalar genellikle enerji tüketiminin ekonomik değişkenler üzerindeki etkisine yoğunlaşmıştır. Enerji güvenliği üzerine yapılan ampirik çalışmaların çoğunluğu ise enerji güvenliği endeksi oluşturma üzerinedir.

Enerji güvenliğini bir bütün olarak ampirik çalışmalarına konu edinen çok az sayıda çalışmadan birisi Le and Nguyen (2019) tarafından yapılmıştır. Söz konusu çalışmada, 20022013 yılları arasındaki dönemde 74 ülkeyi kapsayan bir veri seti ile enerji güvenliğinin ekonomik büyümeye katkıda bulunup bulunmadığını incelenmektedir. Enerji güvenliğinin 5 farklı yönünü içeren 10 enerji güvenliği ölçütü ile farklı gelir seviyelerine dayalı ülkelerin alt örnekleri üzerinde panel veri analizini gerçekleştirilmiş̧ir. Yazarlara göre, elde edilen sonuçlar enerji güvenliğinin hem tüm örnek ülke hem de alt örneklemler için ekonomik büyümeyi arttırdığını göstermektedir. Ayrıca enerji yoğunluğu ve karbon yoğunluğu değişkenleriyle ölçülen enerji güvensizliği ekonomik büyümeyi olumsuz etkilemektedir. Bulgular, küresel düzeyde ekonomik gelişme, enerji güvenliği ve iklim değişikliğinin azaltılması için enerjinin bu üç ajanda arasında bağlantı olduğu için bütünleşik temalar olarak takip edilmesi gerektiğini göstermektedir. Enerji güvenliğinin ampirik çalı̧̧maya konu olan bir diğer çalışma Stavytskyy vd. (2018) çalışmasında 1997-2016 yıllarını kapsayan 29 Avrupa

\section{Veri Seti ve Metodolojisi}

Panel veri; hane halkları, firmalar ve ülkelerin bir yatay kesit üzerinde çeşitli zaman periyotları boyunca gözlemlerin bir araya getirilmesini ifade etmektedir (Baltagi, 2005: 1). Bu bölümde politik istikrarsızlık, enerji güvenliği ve ekonomik büyüme ilişkisi bir panel veri oluşturularak incelenmiştir. $\mathrm{Bu}$ amaçla (1) nolu denklem kurulmuştur. Ekonomik büyümeyi temsil etmesi için kişi başı GSYH'den faydalanılmıştır. Denklemde verilen değişkenler ve açıklamaları Tablo 2'de verilmiştir.

$$
\ln \operatorname{pergdp} p_{i, t}=\beta_{0}+\beta_{1} \ln e n \sec _{i, t}+\beta_{2} \ln p i_{i, t}+\varepsilon_{i, t}
$$


Tablo 2. Analizde Kullanılan Veriler ve Açıklamaları

\begin{tabular}{|c|c|}
\hline Değişken & Açıklama \\
\hline lnpergdp & $\begin{array}{l}\text { Kişi başı GSYH. Genel olarak Dünya Bankası } \\
\text { tarafindan elde edilen veriler kullanılmıştır. Eksik } \\
\text { veriler IMF, UNCTAD, CIA ve Butter (2015)'den } \\
\text { tamamlanmışır. }\end{array}$ \\
\hline Inensec & $\begin{array}{l}\text { Global Energy Institute tarafından enerji tüketimi en } \\
\text { yüksek } 75 \text { ülke için yayınladığı "Enerji Güvenliği } \\
\text { Risk Skoru"dur. Rakamsal artış riskin arttığını } \\
\text { göstermektedir. }\end{array}$ \\
\hline Inpi & $\begin{array}{l}\text { Dünya Bankası tarafından yayınlanan "Politik İstikrar } \\
\text { ve Şiddet/Terörizm Yokluğu" verisidir. Rakamsal } \\
\text { azalıs politik riskin arttığını göstermektedir. }\end{array}$ \\
\hline Ülkeler & $\begin{array}{l}\text { Türkiye, Suudi Arabistan, İran, BAE, Mısır, İsrail, } \\
\text { Irak, Cezayir, Katar, Kuveyt, Fas, Umman, Libya, } \\
\text { Bahreyn ve Suriye. }\end{array}$ \\
\hline
\end{tabular}

Enerji Güvenliği Risk Skoru, Orta Doğu'da yer alan ülkelerden 15 ülke için mevcut olmasından dolayı yapılan analiz 15 ülkeyi kapsamaktadır. Bunun yanında, politik istikrarsızlık değişkenin 1996 yılından başlaması, Enerji Güvenliği Risk Skorunun ise 2014 y1lına kadar mevcut olmasından dolayı analiz 1996-2014 yıllarını kapsamaktadır. Verilerin aynı türden ifade edilebilmesi için logaritması alınmıştır. Negatif verilerin logaritması hesaplanamayacağından pi değişkeninin tüm değerlerine 5 puan eklenerek negatiflikten kurtarılmıştır.

Panel veri seti, zaman boyutunu da içermesinden dolayı beraberinde zaman serisi özelliklerini ve sorunlarını da getirmektedir. Bu bağlamda verilerde birim kökün varlığı tespit edilirse, sahte regresyon sorunu panel veri analizinde de ortaya çıkmaktadır. Bu nedenle öncelikle panel birim kök incelemesinin yapılması gerekmektedir (Kök ve Şimşek, 2006). Birim kökün varlığı serinin durağan olmadığını göstermektedir. Durağanlık kavramı ise stokastik bir sürecin birinci (ortalama) ve ikinci (varyans ve otokovaryans) momentleri doğrusal zamanda değişmez (zamandan bağımsız) olduğu durumu ifade etmektedir. Durağan olmayan bir zaman serisi d defa fark1 alınarak durağan hale dönüştürülebiliyorsa bu seri d'inci dereceden bütünleşiktir ve bu durum I (d) şeklinde gösterilir (Uçan, 2011: 145-148).

Bu çalışmada Levin, Lin ve Chu (2002) ve Im, Pesaran, Shin (2003) birim kök testlerinden yararlanılmıştır. Levin, Lin ve Chu (2002), her bir zaman serisinin durağan olduğu alternatif hipotezine karşı birim kök içerdiği boş hipotezi test etmek için havuzlanmış kesitsel zaman serisi verilerini kullanan homojen paneller için bir prosedür geliştirmiştir (Levin, Lin ve Chu, 2002:18). LLC testi, sıfir hipotezinde paneldeki her birim bütünleşik artıkları (residual) içerir durumunu, alternatif hipotezinde ise tüm birimler durağan artıklar içerir durumunu test etmekte; paneldeki her grubun birim kök içerip içermediğinin analizi yapılmaktadır (Çelik vd., 2008). Levin, Lin ve Chu (2002), Denklem (2)'de verilen temel ADF spesifikasyonunu dikkate alarak panel birim kök testini açıklamaktadır (Seshaiah ve Tripathy, 2018: 578-579):

$$
\Delta Y_{i, t}=\left(\rho_{i}-1\right) Y_{i, t-1}+\sum_{j=1}^{\varphi} \beta_{i, t} \Delta Y_{i, t-j}+\delta X_{i, t}+\varepsilon_{i, t}
$$

Burada $\Delta Y_{i, t}, Y_{i, t}$ 'nin panel veri değişkeni olduğu fark terimi, $n$ fark terimi için gecikme sayısı, $X_{i, t}$ modeldeki eksojen değişken ve $\varepsilon_{i, t}$ denklemdeki hata terimidir.
Denklem (2) otokorelasyon ve deterministtik bileşenler düşünülerek aşağıdaki gibi yeniden yazılabilir:

$$
\Delta Y_{i, t}^{*}=\left(\rho_{i}-1\right) Y_{i, t-1}+\sum_{j=1}^{\varphi} \beta_{i, t}^{*} \Delta Y_{i, t-j}+\delta^{*} X_{i, t}^{*}+\varepsilon_{i, t}
$$

Benzer $y_{i, t-1}^{*}$ ikinci katsayı kümesi kullanılarak şu şekilde tanımlanabilir:

$y_{i, t-1}^{*}=Y_{i, t-1}+\sum_{j=1}^{n} \beta_{i, t}^{*} \Delta Y_{i, t-j}+\delta X_{i, t}^{*}$

$\Delta Y_{i, t}^{+}$ve $y_{i, t-1}^{+}, \Delta Y_{i, t}^{*}, y_{i, t-1}^{*}$ 'in regresyon standart hatası $s_{i}$ 'ye bölünmesiyle elde edilir. Burada Denklem (11)'deki her bir ADF den $s_{i}$ standart hata hesaplanır. Son olarak $\alpha$ katsayısı denklem (5) kullanılarak hesaplanır.

$$
\Delta Y_{i, t}^{+}=\left(\rho_{i}-1\right) y_{i, t}^{+}+\xi_{i, t}
$$

Yukarıdaki denklemde elde edilen $\alpha$ katsayısı, sonlu örnek özelliklerine sahip asimptotik ve normal dağılıma sahip olacaktır. Bununla birlikte, t istatistiği eksi sonsuza doğru saparsa, Levin, Lin ve Chu (2002) tarafından gösterildiği gibi, iyi tanımlanmış bir sınırlayıcı dağılımına yakınsama sağlamak için yeniden yerleştirilmeli ve normalleştirilmelidir. Bu yüzden istatistik değeri aşağıdaki gibi modifiye edilmektedir:

$t^{*}=\left(t_{\varphi}-N \tilde{T} \hat{S}_{N T} \operatorname{STD}(\hat{\Phi}) \mu_{m} T\right) / \sigma_{m} T$

Burada $\tilde{T}$ örnek büyüklüğü, $S T D(\hat{\Phi}), \hat{\Phi}$ 'nın standart sapmasidir.

$\hat{S}_{N T}=\frac{1}{N} \sum_{i=1}^{N} \hat{s}_{i}$

Panel verinin birim birim kök içerdiğini ifade eden hipotez:

$H_{0}: \Phi_{i}=\rho_{i}-1=0, i=1, \ldots, N$

Panel verinin birim birim kök içermediğini ifade eden alternatif hipotez:

$H_{1}: \Phi_{i}=\rho_{i}-1 \neq 0$

şeklinde verilir.

Im, Pesaran ve Shin (2003) panel birim kök testi bireysel birim kök istatistiklerinin ortalamasına dayanan dinamik heterojen paneller için geliştirilmiştir (Im, Pesaran ve Shin, 2003: 53). Bu test her bir yatay kesit için ayrı ayrı birim kök testi olup olmadığını test etmektedir.

$t=1,2, \ldots, T$ olmak üzere IPS panel birim kök testi için model şu şekildedir (Seshaiah ve Tripathy, 2018: 580):

$Y_{i t}=\alpha+\beta Y_{i t-1}+\varepsilon_{i t}$

Bu denklem Dicky Fuller formatında

$Y_{i t}=\alpha+\beta Y_{i t-1}+\varepsilon_{i t}, t=1,2, \ldots, T$

olarak yazılabilir. Yukarıdaki birinci derece Auto Regressive (AR) model $Y_{i t}$ bağımlı değişken ve panel çerçevesinde birinci gecikmeli bağımsız değişken içerir. Panel çerçevesinde 1 'den $N$ 'ye kadar $i$ değişkenleri yatay kesit birimlerini, $\varepsilon_{i t}$ denklemin hata terimini gösterir. $\mathrm{Bu}$ denklem $t=1,2,3, \ldots, T$ olmak üzere Augmented Dicky Fuller formatında 
$\Delta Y_{i t}=\alpha_{i}+\beta_{i} \Delta Y_{i t-1}+\sum_{j=1}^{p i} \theta \Delta Y_{i t-j}+\varepsilon_{i t}$

olarak ifade edilir. Sıfır hipotezi veya birim kök hipotezi $H_{0}: \beta=1$ olarak ifade edilebilir. Bireysel serilerde birim kökleri test etmek için tahmini $\mathrm{t}$ istatistikleri,

$\bar{t}_{N T}=\frac{1}{N} \sum_{i=1}^{N} t_{i T}\left(p_{i} \theta_{i}\right)$

biçimindedir. $\bar{t}_{N T}$ standartlaştırılmıştır ve standartlaştırılmış $\bar{t}_{N T}$ istatistiğinin $N$ ve $T \rightarrow \infty$ standart normal dağılıma yakınsadığı gösterilmiştir. IPS, $N$ ve $T$ küçük olduğunda $\bar{t}_{N T}$ testinin daha iyi sonuçlar verdiğini göstermektedir.

Değişkenler arasında uzun dönemli katsayıları tahmin etmeden önce değişkenler arasında bir eşbütünleşme ilişkisinin doğrulanması gerekmektedir. $\mathrm{Bu}$ amaçla literatürde kullanılan eşbütünleşme testlerinden olan Pedroni ve Kao testleri, Engle-Granger (1987) eşbütünleşme testinin panel veriler için genişletilmiş, iki aşamalı (artık bazlı) eşbütünleşme testlerine dayanmaktayken, Fisher testi Johansen testinin kombine edilmiş halidir.

Pedroni (1999, 2004) birden fazla regrese sahip dinamik panellerde eşbütünleşme yokluğunu test etmek ve bu testler için yaklaşık kritik değerleri hesaplamak için artık bazlı bir yöntem açıklamaktadır. Burada ilk adım, hipotezlenen koentegrasyon regresyonundan regresyon artıklarını hesaplamaktır. Genel durumda denklem $t=1, \ldots, T$; $i=1, \ldots, N ; m=1, \ldots, M$ için

$y_{i, t}=\alpha_{i}+\delta_{i} t+\beta_{1 i} x_{1 i, t}+\beta_{2 i} x_{2 i, t}+\cdots+\beta_{M i} x_{M i, t}+e_{i, t}$

şeklindedir. Burada $T$ zaman içindeki gözlem sayısını, $N$ paneldeki bağımsız üyeleri, $M$ regresyondaki değişkenlerin sayısını göstermektedir. Pedroni dördü kesit içi (panel eşbütünleşme), üçü kesitlerarası (grup ortalama panel eşbütünleşme) olmak üzere eşbütünleşmenin yokluğu hipotezini test eden yedi test önermiştir:

\section{Kesit İçi Panel Essbütünlessme Testleri (Within):}

Panel $v$ (variance ratio statistic):

$T^{2} N^{3 / 2} Z_{\hat{v} N, T} \equiv T^{2} N^{3 / 2}\left(\sum_{i=1}^{N} \sum_{t=1}^{T} \hat{L}_{11 i}^{-2} \hat{e}_{i, t-1}^{2}\right)^{-1}$

Panel rho (Panel $\rho-$ Statistik) :

$T \sqrt{N} Z_{\hat{\rho}_{N, T}-1} \equiv T \sqrt{N}\left(\sum_{i=1}^{N} \sum_{t=1}^{T} \hat{L}_{11 i}^{-2} \hat{e}_{i, t-1}^{2}\right)^{-1} \sum_{i=1}^{N} \sum_{t=1}^{T} \hat{L}_{11 i}^{-2}\left(\hat{e}_{i, t-1} \Delta \hat{e}_{i, t}-\hat{\lambda}_{i}\right)$

PanelPP (Panelt-Statistik; non-parametric) :

$Z_{t N, T} \equiv\left(\tilde{\sigma}_{N, T}^{2} \sum_{i=1}^{N} \sum_{t=1}^{T} \hat{L}_{11 i}^{-2} \hat{e}_{i, t-1}^{2}\right)^{-1 / 2} \sum_{i=1}^{N} \sum_{t=1}^{T} \hat{L}_{11 i}^{-2}\left(\hat{e}_{i, t-1} \Delta \hat{e}_{i, t}-\hat{\lambda}_{i}\right)$

Panel ADF (Panelt-Statistik; parametric) :

$Z_{t N, T}^{*} \equiv\left(\tilde{s}_{N, T}^{* 2} \sum_{i=1}^{N} \sum_{t=1}^{T} \hat{L}_{11 i}^{-2} \hat{e}_{i, t-1}^{* 2}\right)^{-1 / 2} \sum_{i=1}^{N} \sum_{t=1}^{T} \hat{L}_{11 i}^{-2} \hat{e}_{i, t-1}^{* 2} \Delta \hat{e}_{i, t}^{*}$
Kesitlerarası Panel Essbütünleșme Testleri (Between Tests):

Grup rho (Grup $\rho-$ Statistik) :

$T N^{-1 / 2} \tilde{Z}_{\hat{\rho}_{N, T}-1} \equiv T N^{-1 / 2} \sum_{i=1}^{N}\left(\sum_{t=1}^{T} \hat{e}_{i, t-1}^{2}\right)^{-1} \sum_{i=1}^{T}\left(\hat{e}_{i, t-1} \Delta \hat{e}_{i, t}-\hat{\lambda}_{i}\right)$

Grup PP (Grup t-Statistik; non-parametric) :

$N^{-1 / 2} \tilde{Z}_{t_{N, T}} \equiv N^{-1 / 2} \sum_{i=1}^{N}\left(\hat{\sigma}_{i}^{2} \sum_{t=1}^{T} \hat{e}_{i, t-1}^{2}\right)^{-1 / 2} \sum_{t=1}^{T}\left(\hat{e}_{i, t-1} \Delta \hat{e}_{i, t}-\hat{\lambda}_{i}\right)$

Grup ADF (Grupt-Statistik; parmetric):

$N^{-1 / 2} \tilde{Z}_{t N, T}^{*} \equiv N^{-1 / 2} \sum_{i=1}^{N}\left(\sum_{t=1}^{T} \hat{s}_{i}^{* 2} \hat{e}_{i, t-1}^{* 2}\right)^{-1 / 2} \sum_{t=1}^{T} \hat{e}_{i, t-1}^{*} \Delta \hat{e}_{i, t}^{*}$

Panel ve grup ortalama istatistiklerinin her biri için asimptotik dağılımlar şu şekilde ifade edilebilir:

$\frac{\chi_{N, T}-\mu \sqrt{N}}{\sqrt{v}} \Rightarrow N(0,1)$

Burada $\chi_{N, T}$, yukarıda ifade edilen kesit içi ve kesitlerarası istatistiklerin her biri için uygun şekilde standardize edilmiş ( $\mathrm{N}$ ve $\mathrm{T}$ boyutlarına göre) formuyken, $\mu$ ve $v$ değerleri her testin ortalaması ve varyansıdır.

Engle-Granger iki aşamalı eşbütünleşme testlerinden bir diğeri Kao Eşbütünleşme testidir. Kao (1999), Dickey Fuller (DF) ve Augmented Dickey Fuller (ADF) temelli eşbütünleşme testleri sunmaktadır. Kao'nun DF tipi testi aşağıdaki modeli takip etmektedir:

$$
\begin{aligned}
& y_{i t}=\alpha_{i}+\beta x_{i t}+e_{i t}, \quad i=1, \ldots, N, \quad t=1, \ldots, T \\
& y_{i t}=y_{i t-1}+u_{i t} \\
& \chi_{i t}=\chi_{i t-1}+\varepsilon_{i t}
\end{aligned}
$$

$\mathrm{Bu}$ modelle $\mathrm{DF}$ testi, tahmin yapılan kalıntılardan hesaplanabilir:

$\hat{e}_{i t}=p \hat{e}_{i t-1}+v_{i t}$

Durağan olmayan sıfır hipotezini test etmek, yokluk hipotezi (eşbütünleşme yoktur) $H_{0}: \rho=1$ olarak yazılabilir. ADF testi, tahmin yapılan kalıntılardan hesaplanabilir:

$\hat{e}_{i t}=p \hat{e}_{i t-1}+\sum_{j=1}^{p} \phi_{j} \Delta \hat{e}_{i t-j}+v_{i t p}$

Eşbütünleşmenin yokluğu altında ADF test formu:

$t_{A D F}=\frac{(\hat{p}-1)\left[\sum_{i=1}^{N}\left(e_{i} Q_{i} e_{i}\right)\right]^{1 / 2}}{s_{v}}$

şeklindedir. Burada eşbütünleşmenin yokluğu hipotezi $H_{0}: \rho=1$ t istatistiğine dayanmaktadır.

Fisher (1932), özel bağımsız test sonuçlarını kullanan birleştirilmiş bir test elde etmiştir. Maddala ve Wu (1999), 
Johansen testlerini birleştirerek panel verilerinde eş bütünleşme testine alternatif bir yaklaşım önermek için Fisher'ın sonuçlarını kullanmışlardır. Bu test Johansen Fisher Panel Eşbütünleşme Testi olarak adlandırılmaktadır (Arlt ve Mandel, 2014: 279).

Johansen (1988), iki farklı yaklaşım önermektedir; bunlardan biri olasılık istatistiklerinin iz istatistiği, diğeri ise durağan olmayan zaman serilerinde eşbütünleşme vektörlerinin varlığını belirlemek için maksimum özdeğer istatistiğidir. İz istatistikleri ve maksimum özdeğer istatistikleri sirasıyla Denklem (29) ve Denklem (30)'da gösterilmiştir (Morshed, 2010: 17).

$$
\begin{aligned}
& \lambda_{i z}(r)=-T \sum_{i=r+1}^{n} \ln \left(1-\hat{\lambda}_{i}\right) \\
& \lambda_{\text {mak }}(r, r+1)=-T \ln \left(1-\hat{\lambda}_{r+1}\right)
\end{aligned}
$$

Eğer $\pi_{i}$ yatay kesit $i$ için bireysel eşbütünleşme testinden elde edilen $p$ değeri ise, o zaman panel için sıfır hipotezi:

$$
\chi_{2 N}^{2}=-2 \sum_{i=1}^{N} \log _{e}\left(\pi_{i}\right)
$$

Eşbütünleşme ilişkinin varlığı tespit edilmesi durumunda Pedroni (2000) tarafindan önerilen Tam Modifiye En Küçük Kareler Yöntemi (FMOLS-Fully Modified Ordinary Least Squares) ile uzun dönem katsayıların tahmini yapılabilir. Heterojen panellerde eşbütünleşme regresyonlarının tahmini için Pedroni (2000) aşağıdaki denklemi kullanmıştır:

$$
\begin{aligned}
& y_{i t}=\alpha_{i}+\beta x_{i t}+\mu_{i t} \\
& x_{i t}=x_{i t-1}+\varepsilon_{i t}
\end{aligned}
$$

Denklem (31)'de hata terimleri durağan bir süreçtir. Dolayısıyla $y_{i t}$ birinci dereceden bütünleşik ise $y_{i t}$ ve $x_{i t}$ arasında eşbütünleşme ilişkisi vardır. Böylece, $\beta$ tahmin edilmesi gereken uzun dönem eşbütünleşme vektörünü göstermektedir. Panel FMOLS tahmincisinde panel için eşbütünleşme vektörü elde edilirken birinci aşamada eşitlik (31)'deki model her bir yatay kesit için FMOLS tahmincisi kullanılarak tahmin edilmektedir. İkinci aşamada her bir yatay kesite ait FMOLS tahmininden elde edilen eşbütünleşme katsayılarının ortalaması alınmaktadır. Panel için eşbütünleşme vektörü ve panel eşbütünleşme katsayısına ilişkin t-istatistiği aşağıdaki gibi hesaplanmaktadır (Nazlıoğlu, 2010: 98-99):

$$
\begin{aligned}
& \hat{\beta}_{G F M}^{*}=N^{-1} \sum_{i=1}^{N} \beta_{F M, i}^{*} \\
& t_{\hat{\beta}_{G F M}^{*}}=N^{-1 / 2} \sum_{i=1}^{N} t_{\hat{\beta}_{F M, i}^{*}}
\end{aligned}
$$

Burada, $\hat{\beta}_{G F M}^{*}$ her bir yatay kesit için FMOLS tahmininden elde edilen eşbütünleşme katsayısını, $t_{\hat{\beta}_{G F M}^{*}}$ paneli oluşturan her bir yatay kesit için yapılan FMOLS tahmininden elde edilen eşbütünleşme katsayısına ilişkin t-istatistiğini göstermektedir.

Kısa dönem katsayıların tespiti için klasik model, rassal etkiler modeli ve sabit etkiler modeli arasında seçim yapılması gerekmektedir. Ayrıca klasik modelin dışında bir model kullanılacaksa kullanılacak modelde tek yönlü zaman ya da kesit etki modeli mi yoksa çift yönlü etki modelinin mi geçerli olduğu tespit edilmelidir. Hangi modelin geçerli olduğunun tespiti için kullanılan yöntemlerden biri olan F İstatistiği klasik model ile sabit etkili model arasında ${ }^{2}$ geçerli model seçiminde yardımcı olan testlerdendir. Modelde tek ya da çift yönlü etkilerin tespit edilmesi için EKK tahmin yöntemi sonucu elde edilen hata terimleri kullanılmaktadır. Aşağıda verilen Denklem (35) ile tek yönlü sabit kesit etki modeli, Denklem (36) ile tek yönlü sabit zaman etki modeli, Denklem (37) ile çift yönlü sabit kesit etki modeli açıklanmaktadır (Baltagi, 2005: 11-14; Hotunluoğlu ve Özçağ, 2012: 360-362)33.

$$
\begin{array}{ccc}
u_{i t}= & H_{0}= & F= \\
\mu_{i}+v_{i t} & \mu_{1}=\mu_{2}=\ldots=0 & \frac{(R R S S-U R S S) /(N-1)}{U R S S /(N T-N-K)} \\
\lambda_{t}+v_{i t} & \lambda_{1}=\lambda_{2}=\ldots=0 & \frac{(R R S S-U R S S) /(N-1)}{U R S S /(N T-N-K)} \\
\mu_{i}+\lambda_{i}+v_{i t} & \mu=\lambda=\ldots=0 & \frac{(R R S S-U R S S) /(N+K-1)}{U R S S /(N T-N-K+1)}
\end{array}
$$

Klasik model ile rassal etki modelden hangi yöntemin kullanılmasının uygun olduğuna karar verilmesinde literatürde en sık kullanılan Breusch ve Pagan (1980) LM test istatistiğ ${ }^{4}{ }^{4}$ aşağıda verilen Denklem (38) ile rassal kesit etkisini, Denklem (39) ile rassal zaman etkisini, Denklem (40) ile çift yönlü rasssal etki yokluk hipotezini test etmektedir (Baltagi, 2005: 59-60).

$$
\begin{aligned}
& L M_{\mu}=\frac{N T}{2(T-1)}\left[1-\frac{\tilde{u}\left(I_{N} \otimes J_{T}\right) \tilde{u}}{\tilde{u}^{\prime} \tilde{u}}\right]^{2} \quad H_{0}^{a}: \sigma_{\mu}^{2}=0 \\
& L M_{\lambda}=\frac{N T}{2(N-1)}\left[1-\frac{\tilde{u}^{\prime}\left(J_{N} \otimes I_{T}\right) \tilde{u}}{\tilde{u}^{\prime} \tilde{u}}\right]^{2}
\end{aligned}
$$

$L M_{\mu}+L M_{\lambda}$

$$
H_{0}: \sigma_{\mu}^{2}=\sigma_{\lambda}^{2}=0
$$

Hem F Testi hem de LM Testi sonucunda klasik modelin uygulanamayacağı sonucunun çıkması durumunda rassal ve sabit etki modellerinden birisi tercih edilmelidir. Bu iki test arasında hangisinin uygulanacağına ise Hausman Testi

\footnotetext{
${ }^{2} \mathrm{H}_{0}$ kabul ise klasik model; $\mathrm{H}_{0}$ red ise sabit etki modeli.

${ }^{3} u_{i}$ gözlemlenemeyen kesit ekişi, $\lambda_{t}$ gözlemlenemeyen zaman etkisini, $v_{i t}$ rassal hata terimini ifade etmektedir. RRSS k1sitl modelin hata kareleri toplamı, URSS kısıtsız modelin hata kareleri toplamin 1 ifade etmektedir.
}

${ }^{4} \mathrm{H}_{0}$ kabul ise klasik model; $\mathrm{H}_{0}$ red ise rassal etki modeli. (s) . 
sonucunda karar verilir. Hausman İstatistiği şu şekilde ifade edilebilir (Tar1, 2011: 494):

$$
\left(\hat{\beta}_{S E}+\hat{\beta}_{R E}\right)^{\prime}\left[\operatorname{Var}\left(\hat{\beta}_{S E}-\operatorname{Var}\left(\hat{\beta}_{R E}\right)\right)\right]^{-1}\left(\hat{\beta}_{S E}-\hat{\beta}_{R E}\right)=\chi_{k}^{2}
$$

Yokluk hipotezinin kabulü rassal etkiler modelini, alternatif hipotezin kabulü ise sabit etkiler modelini işaret etmektedir.

\section{Ampirik Sonuçlar}

$\mathrm{Bu}$ bölümde öncelikle değişkenlerin birim kök içerip içermediğinin analizi yapıldıktan sonra, uygun sonuçlar çıkması halinde eşbütünleşme analizi yapılacaktır. Bu çalışmada LLC (Levin, Lin ve Chu), IPS (Im, Pesaran, Shin) birim kök testleri uygulanmıştır. Tablo 3'de Levin, Lin ve Chu (2002) ve Im, Pesaran, Shin (2003) birim kök testi sonuçları verilmiştir.
Tablo 3. Birim Kök Test Sonuçları (LLC ve IPS)

\begin{tabular}{|c|c|c|c|c|}
\hline \multirow{3}{*}{ Değişken } & \multicolumn{4}{|c|}{ Levin, Lin ve Chu t istatistik (LLC) } \\
\hline & \multicolumn{2}{|c|}{ Düzey } & \multicolumn{2}{|c|}{ Birinci Fark } \\
\hline & İst. & p-value & İst. & $\mathrm{p}$-value \\
\hline pergdp & $-1,55240$ & 0,0603 & $-9,22516$ & 0,0000 \\
\hline pi & $-0,10377$ & 0,4587 & $-6,75302$ & 0,0000 \\
\hline ensec & 2,06499 & 0,9805 & $-7,98119$ & 0,0000 \\
\hline \multirow{3}{*}{ Değişken } & \multicolumn{4}{|c|}{ Im, Pesaran and Shin W-stat (IPS) } \\
\hline & \multicolumn{2}{|c|}{ Düzey } & \multicolumn{2}{|c|}{ Birinci Fark } \\
\hline & İst. & p-value & İst. & p-value \\
\hline pergdp & $-0,33935$ & 0,3672 & $-619,149$ & 0,0000 \\
\hline pi & $-0,71911$ & 0,2360 & $-741,008$ & 0,0000 \\
\hline ensec & 0,01064 & 0,5042 & $-572,505$ & 0,0000 \\
\hline
\end{tabular}

Tablo 3 incelendiğinde her iki birim kök testi sonuçlarında da tüm değişkenlerin düzeyde birim kök içerdiği, birinci farkı alındığından birim kökten kurtulduğu görülmektedir. Kisaca değişkenler I(1) seviyesinde durağan hale gelmektedir. $\mathrm{Bu}$ sonuç eşbütünleşme analizinin yapılabileceğini göstermektedir. $\mathrm{Bu}$ doğrultuda yapılan eşbütünleşme test sonuçları Tablo 4'de verilmiştir. İlk olarak verilen Pedroni Eşbütünleşme sonuçlarına göre 11 test istatistiğinden 8'inde eşbütünleşme yoktur hipotezi reddedilerek, alternatif hipotez olan eşbütünleşmenin varlığı kabul edilmiştir. Aynı şekilde Kao Eşbütünleşme Testi ve Johansen Fisher Panel Eşbütünleşme Testi sonuçları da eşbütünleşme ilişkisinin varlığını teyit etmektedir.

Tablo 4. Eşbütünleşme Test Sonuçları

\begin{tabular}{llccc}
\hline & \multicolumn{2}{c}{ Pedroni Eşbütünleşme Testi } & & \\
\hline Kesit İçi Testler (Within) & t-ist. & Olasılık & Ă̆ırlık, t- ist. & Olasılık \\
Panel v & $-0,791242$ & 0,7856 & $-2,694330$ & 0,9965 \\
Panel rho & $-3,966839$ & $0,0000^{* * *}$ & $-2,328830$ & $0,0099^{* * *}$ \\
Panel PP & $-8,034342$ & $0,0000^{* * *}$ & $-8,197642$ & $0,0000^{* * *}$ \\
Panel ADF & $-8,103650$ & $0,0000^{* * *}$ & $-8,059380$ & $0,0000^{* * *}$ \\
Kesitlerarası Testler (Between Tests) & & t-ist. & \multicolumn{1}{c}{ Olasılık } \\
Group rho-Statistic & & $-0,626578$ & 0,2655 \\
Group PP-Statistic & & $-9,824519$ & $0,0000^{* * *}$ \\
Group ADF-Statistic & & $-7,592429$ & $0,0000^{* * *}$ \\
\hline
\end{tabular}

\begin{tabular}{|c|c|c|c|c|}
\hline \multicolumn{5}{|c|}{ Kao Eşbütünleşme Testi } \\
\hline \multicolumn{5}{|l|}{ ADF } \\
\hline t-ist. & \multicolumn{4}{|c|}{ Olasılık } \\
\hline$-2,439652$ & \multicolumn{4}{|c|}{$0,0074 * * *$} \\
\hline \multicolumn{5}{|c|}{ Johansen Fisher Panel Eşbütünleşme Testi } \\
\hline Eşbütünleşme Hipotezleri & $\begin{array}{l}\text { Fisher İst. } \\
\text { (İz testi) }\end{array}$ & Olasılık & $\begin{array}{l}\text { Fisher İst. } \\
\text { (mak. özdeğer) }\end{array}$ & Olasılık \\
\hline Yok & 279.9 & $0.0000 * * *$ & 205.2 & $0.0000 * * *$ \\
\hline En çok 1 & 120.1 & $0.0000 * * *$ & 106.5 & $0.0000 * * *$ \\
\hline En çok 2 & 62.82 & $0.0004 * * *$ & 62.82 & $0.0004 * * *$ \\
\hline
\end{tabular}

Not :Lag uzunluğu Akaike Bilgi Kriterine göre belirlenmiştir. ***\%1, **\%5, *\%10.

Uzun dönemli ilişkinin varlığının bulunmasının ardından değişkenlerin uzun dönem katsayıları FMOLS yöntemi ile tahmin edilmiş olup, sonuçlar Tablo 5'de verilmiştir.

Tablo 5. FMOLS (Panel Fully Modified Least Squares) Test Sonuçları

\begin{tabular}{llll}
\hline Değişken & Katsayı & t ist. & p-value \\
\hline$\Delta$ Inensec & $-0,414448$ & $-3,057127$ & $0,0025^{* * *}$ \\
$\Delta$ Inpi & 0,255783 & 1,869909 & $0,0629^{*}$ \\
$\mathbf{R}^{\mathbf{2}}$ & 0,188107 & & \\
\hline Not $\quad: * * * \% 1, * * \% 5, * \% 10$. & &
\end{tabular}

Tablo 5'de verilen FMOLS sonuçlarına göre, politik istikrardaki \%1 artış, \%10 anlamlılık seviyesinde kişi başı GSYH'yi \%0,25 artırırken; enerji güvenliği riskindeki $\% 1$ artış, \%1 anlamlılık seviyesinde kişi başı GSYH'yi \%0,41 azaltmaktadır. Ortaya çıkan bu sonuç beklentiler ile uyumludur.

Kısa dönem katsayıların tespitinde rassal ve sabit etkili modellerden uygun olana karar vermek için bazı ön testler yapılması gerekmektedir. Kısa dönem katsayılarının hesaplanmasında klasik model, rassal etkili model ve sabit 
etkili modelden hangisinin kullanılacağı, klasik modelin dışında bir model kullanılacaksa tek yönlü etki (zaman veya kesit) modellerinden birisi mi yoksa çift yönlü etki modellerinden birisinin mi kullanılacağı konusunda karar vermek için yapılan testler ve sonuçları Tablo 6'da verilmiştir.

Tablo 6. Uygun Modelin Seçilmesi Üzerine Yapılan Test Sonuçları

\begin{tabular}{|c|c|c|c|c|c|}
\hline Test & Etki Türü & İst. & Olasılık & $\mathbf{H}_{\mathbf{0}}$ & Sonuc \\
\hline \multirow{3}{*}{ 苞 } & Kesit etkisi & 0,13538 & 0,9999 & Sabit kesit etki yoktur. & Kabul \\
\hline & Zaman etkisi & 5,70398 & 0,0000 & Sabit zaman etki yoktur & Red \\
\hline & Çift yönlü & 3,06609 & 0,0000 & Sabit çift yönlü etki yoktur & Red \\
\hline \multirow{3}{*}{ 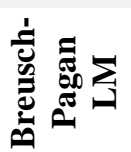 } & Kesit etkisi & 5,96433 & 0,0146 & Rassal kesit etki yoktur. & Red \\
\hline & Zaman etkisi & 7,29778 & 0,0000 & Rassal zaman etki yoktur & Red \\
\hline & Çift yönlü etki & 7,89422 & 0,0000 & Rassal çift yönlü etki yoktur & Red \\
\hline \multirow{3}{*}{ 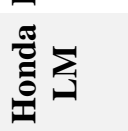 } & Kesit etkisi & $-2,44220$ & - & Rassal kesit etki yoktur. & - \\
\hline & Zaman etkisi & 8,54271 & 0,0000 & Rassal zaman etki yoktur & Red \\
\hline & Çift yönlü etki & 4,31371 & 0,0000 & Rassal çift yönlü etki yoktur & Red \\
\hline \multirow{3}{*}{ 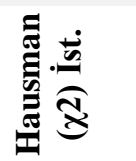 } & Kesit etkisi & 0,19132 & 0,9088 & Rassal Kesit etki & Kabul \\
\hline & Zaman etkisi & 8,37541 & 0,0152 & Rassal zaman etki & Red \\
\hline & Çift yönlü etki & 6,34689 & 0,0419 & Çift yönlü rassal etki & Red \\
\hline
\end{tabular}

Klasik model ile sabit etkili model arasındaki tercihi belirten $\mathrm{F}$ Testi sonuçları incelendiğinde kesit etkisinin kabul edildiği model ${ }^{5}$ dışındaki diğer sonuçlar sabit etkinin varlığını desteklemektedir. Rassal etkili model ile klasik model arasında tercihi belirten Breusch-Pagan LM sonuçları incelendiğinde rassal etkili modelinin varlığı kabul edilmiştir. Honda LM zaman ve çift yönlü etki modellerinde klasik modele karşı rassal etkinin varlığ kabul edilirken kesit etkisi negatif değer aldığ1 için rassal etki tahmini geçersizdir. LM testleri bir arada düşünüldügünde tek yönlü rassal zaman etkisi ve çift yönlü rassal etki vardır.

Rassal etki ile sabit etki modelleri arasında hangisine karar verileceğini gösteren Hausman test sonuçları incelendiğinde ${ }^{6}$ kesit etkide rassal etkinin, zaman ve çift yönlü etkide sabit etkili modelin geçerliliği kabul edilmiştir. Rassal kesit etkisi Honda LM testinde negatif değer aldığ için geçersiz olmasından dolayı analizin tek yönlü sabit zaman etkisi ile yapılmasına karar verilmiştir. Tablo 7'de tek yönlü sabit zaman etkili modelin sonuçları verilmiştir.

Tek yönlü zaman etkili sabit modelin tahmin sonuçları incelendiğinde enerji güvenliği değişkeninin \%1 anlamlılık seviyesinde anlamlı iken politik istikrar değişkeninin \%10 (\%5'e çok yakın seviyede) anlamlılık seviyesinde anlamlı olduğunu göstermektedir. Bağımsız değişkenlerin bağımlı değişkeni açıklama oranı \%29'dur. Modelin genel anlamlılığını gösteren $\mathrm{F}$ değeri modelin tümüyle anlamlı olduğunu göstermektedir. $\mathrm{Bu}$ sonuçlara göre enerji güvenliği riskindeki \%1'lik artış kişi başı GSYH'yi \%0,62 azaltmaktadır. Politik istikrardaki $\% 1$ artış ise kişi başı GSYH'yi \%0,35 artırmaktadır.
Tablo 7. Tek Yönlü Zaman Etkili Sabit Modelin Tahmin Sonuçları

\begin{tabular}{lccc}
\hline Değișken & Katsayı & t ist. & p-value \\
\hline$\Delta$ lnensec & $-0,62317$ & $-2,83700$ & $0,00490^{* *}$ \\
$\Delta$ lnpi & 0,34754 & 1,95521 & $0,05170 *$ \\
c & 0,06157 & 5,65001 & $0,00000 * * *$ \\
\hline $\mathbf{R}^{\mathbf{2}}$ & 0,29160 & F-İst. & 5,41608 \\
D-W İst. & 2,27201 & Prob(F-statistic) & 0,00000 \\
\hline Not $: * * * \% 1, * * \% 5, * \% 10$ & &
\end{tabular}

Politik istikrar, enerji güvenliği ve ekonomik büyüme arasındaki Granger nedensellik ilişkisi sonuçları ise Tablo 8 'de verilmiştir. Sonuçlar incelendiğinde enerji güvenliği ile ekonomik büyüme arasında çift yönlü; enerji güvenliğinden politik istikrara ve ekonomik büyümeden politik istikrara olmak üzere tek yönlü Granger Nedensellik ilişkisi tespit edilmiş olup, sonuçlar Şekil 2'de özetlenmiştir.

Tablo 8. Granger Causality Test Sonuçları

\begin{tabular}{lcc}
\hline Hipotez & F İst. & Olasılık \\
\hline $\begin{array}{l}\text { Enerji güvenliği kişi başı gelirin } \\
\text { nedeni değildir. }\end{array}$ & 3,07101 & $0,0175^{* *}$ \\
$\begin{array}{l}\text { Kişi başı gelir enerji güvenliğinin } \\
\text { Granger nedeni değildir. }\end{array}$ & 3,93246 & $0,0043^{* * *}$ \\
$\begin{array}{l}\text { Politik istikrar kişi başı gelirin } \\
\text { Granger nedeni değildir. }\end{array}$ & 1,97156 & 0,1002 \\
\hline $\begin{array}{l}\text { Kişi başı gelir politik istikrarın } \\
\text { Granger nedeni değildir. }\end{array}$ & 2,55759 & $0,0400 * *$ \\
$\begin{array}{l}\text { Politik istikrar enerji güvenliğinin } \\
\text { Granger nedeni değildir. }\end{array}$ & 0,50394 & 0,7329 \\
$\begin{array}{l}\text { Enerji güvenliği politik istikrarın } \\
\text { Granger nedeni değildir. }\end{array}$ & 3,29726 & $0,0121 * *$ \\
\hline Not $* * * \% 1, * * \% 5, * 10$. & &
\end{tabular}

\footnotetext{
${ }^{5}$ Kesit etkisinin kabul edildiği sabit etkili modelde modelin genel anlamlılığını gösteren $\mathrm{F}$ istatistiği modelin anlamsız olduğunu işaret etmektedir.

${ }^{6} \mathrm{H}_{0}$ kabul ise rassal; $\mathrm{H}_{0}$ red ise sabit etki modeli.
} 
Şekil 2. Enerji Güvenliği, Politik İstikrar ve Ekonomik Büyüme Arasındaki Nedensellik

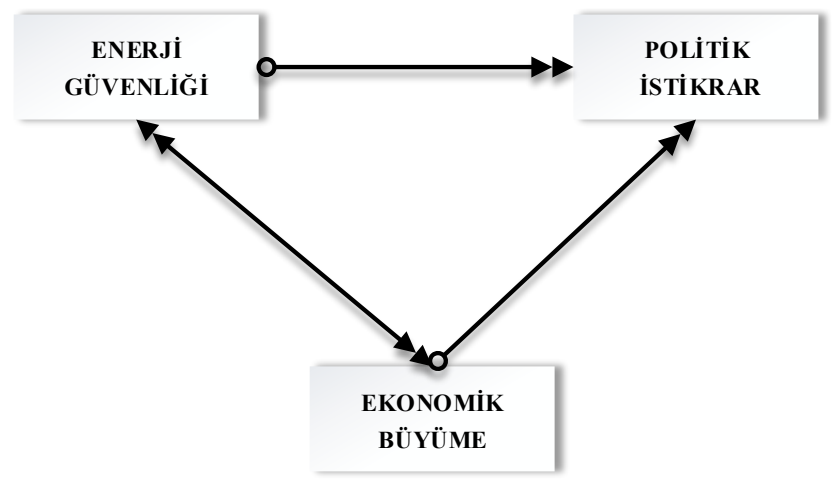

\section{Sonuc}

Bu çalışmada, Orta Doğu'da yer alan 15 ülke için 19962014 yılları arasında ekonomik büyüme ile enerji güvenliği ve politik istikrarsızlık değişkenleri kullanılarak bir panel veri analizi gerçekleştirilmiştir. Yapılan eşbütünleşme analizinde değişkenler arasında uzun dönemli ilişkinin varlığı tespit edilmiştir. Eşbütünleşme ilişkisinin varlığının tespit edilmesinin ardından eşbütünleşme katsayısı tahmini FMOLS yöntemi ile yapılmış; uzun dönemde enerji güvenliği riskinde $\% 1$ artış ekonomik büyümeyi $\% 0,41$ düşürürken, politik istikrardaki $\% 1$ artış ekonomik büyümeyi \%0,25 artırdığı sonucuna varılmıştır. Kısa dönem katsayıların tespiti için çalıştırılan Tek Yönlü Sabit Zaman Etkili Panel EKK sonuçlarına göre enerji güvenliği riskindeki \%1'lik artış ekonomik büyümeyi \%0,62 düşürürken, politik istikrardaki \%1'lik artış büyümeyi \%0,35 artırmaktadır. Değişkenler arasında nedensellik ilişkisi ve nedenselliğin yönünün tespiti için yapılan Panel Granger Nedensellik analiz sonuçlarına göre enerji güvenliği ile büyüme arasında çift yönlü; enerji güvenliğinden politik istikrara ve büyümeden politik istikrara olmak üzere tek yönlü nedensellik ilişkisi tespit edilmiştir.

Ekonometrik analiz sonuçlarına göre, bölge ülkelerinde mevcut literatürle uyumlu olarak politik istikrar bölge ekonomilerini olumlu yönde etkilemektedir. Bu çalışmada enerji güvenliği riskinin ekonomik büyümeye etkisine de yer verilerek (literatürde konuyla ilgili yok denecek kadar az çalışma olmasından dolayı) literatüre önemli bir katkı sağlanması hedeflenmiş olup, ampirik analizden elde edilen sonuçlar enerji güvenliği risk seviyesindeki artışın bölge ekonomilerini olumsuz yönde etkilediğini göstermektedir. $\mathrm{Bu}$ bağlamda enerji güvenliği konusunun bölge ekonomileri için önemli bir politika meselesi olduğu sonucuna varılmıştır. Özellikle enerji güvenliği ile büyüme arasında çift yönlü nedenselliğin varlığının yanında bölge ekonomilerinin petrol ve doğalgaz gelirlerine yüksek bağımlılığı da düşünüldüğünde enerji güvenliği konusunun Orta Doğu ekonomileri için kritik önemde olduğu sonucu ortaya çıkmaktadır.

Orta Doğu'da var olan politik istikrarsızlıklar birçok ekonomik değişkenin yanı sıra dünyanın en önemli petrol ve doğalgaz üreticisi ülkelerin bulunmasından dolayı enerji güvenliğini de tehdit ederek politik istikrarsızlıkların bu ülkeler için ekonomik etkilerini ağırlaştırmaktadır. Politik istikrarsızlıkların çözümü yanında milli menfaatlere uygun enerji politikaları ile sahip olunan zengin petrol ve doğalgaz kaynaklarının daha verimli kullanılması gerekmektedir. $\mathrm{Bu}$ ülkeler için en önemli ekonomik potansiyeli olan enerji kaynaklarını hem enerji yoğun ileri teknoloji ürünler üretmede girdi olarak hem de bu ürünleri üretmede gerekli sermayeyi sağlama açısından kullanılarak önemli bir ekonomik kalkınma ve büyüme hamlesi oluşturulabilir. Fakat politik istikrarsızlık açısından son derece yoğun olaylarla birlikte politik istikrarsızlığın kısır döngüsünün yaşandığı böyle bir bölgede yönetimlerin var olan bu potansiyeli en verimli şekilde kullanarak sağlıklı ekonomi politikaları oluşturmaları ve uygulamaları çok kolay görülmemektedir. Ayrıca bölgede güçlü ve bağımsız liderlerin eksikliği de önemli bir sorundur. Türkiye gibi enerji kaynakları açısından dışa bağımlı bölge ülkeleri ise hem ülkelerindeki hem de bölge genelindeki politik istikrarsızlık olaylarından etkilenmekte, literatürde belirtilen politik istikrarsızlıkların ekonomik değişkenlere olumsuz etkilerini derinden yaşamaktadırlar.

\section{Kaynakça}

Aisen, A., ve Veiga, F. J. (2013). How does political instability affect economic growth?. European Journal of Political Economy, 29, 151-167. https://doi.org/10.1016/j.ejpoleco.2012.11.001

Al, İ., ve Belke, M. (2018). Politik istikrarsızlık ile ekonomik büyüme arasındaki ilişki: MENA ülkeleri için panel nedensellik analizi. Uluslararası Iktisadi ve Idari Incelemeler Dergisi, 271-286. https://doi.org/10.18092/ulikidince.452539

Alcántar-Toledo, J., ve Venieris, Y. P. (2014). Fiscal policy, growth, income distribution and sociopolitical instability. European Journal of Political Economy, 34, 315-331. https://doi.org/10.1016/j.ejpoleco.2014.03.002

Alesina, A., Özler, S., Roubini, N., ve Swagel, P. (1996). Political instability and economic growth. Journal of Economic Growth, 1(2), 189-211. https://doi.org/10.1007/BF00138862

Alesina, A., ve Perotti, R. (1996). Income distribution, political instability, and investment. European Economic Review, 40(6), 1203-1228. https://doi.org/10.1016/0014-2921(95)00030-5

Alper, A. E. (2018). BRICS-T ülkelerinde politik istikrar ve ekonomik performans ilişkisi üzerine bir analiz. Business and Economics Research Journal, 9(1), 49-56. https://doi.org/10.20409/berj.2017.88

Arlt, J., ve Mandel, M. (2014). The reaction function of three central banks of visegrad group. Prague Economic Papers, 23(3), 269-289. https://doi.org/10.18267/j.pep.484

Baltagi, B. (2005). Econometric analysis of panel data (Third Edit). England: John Wiley \& Sons Ltd.

Bellettini, G., Berti Ceroni, C., ve Prarolo, G. (2013). Political persistence and economic growth. European Journal of Political Economy, 31, 165179. https://doi.org/10.1016/j.ejpoleco.2013.05.002 
Breusch, T. S., ve Pagan, A. R. (1980). The Lagrange multiplier test and its applications to model specification in econometrics. The Review of Economic Studies, 47(1), 239-253.

BP (2017). Statistical review of world energy. (Erişim: 12.09.2017),

https://www.bp.com/en/global/corporate/energyeconomics/statistical-review-of-world-energy.html

Brückner, M., ve Gradstein, M. (2015). Income growth, ethnic polarization, and political risk: Evidence from international oil price shocks. Journal of Comparative Economics, 43(3), 575-594. https://doi.org/10.1016/j.jce.2014.05.005

Butkiewicz, J. L., ve Yanikkaya, H. (2005). The impact of sociopolitical instability on economic growth: Analysis and implications. Journal of Policy Modeling, 27(5), 629-645. https://doi.org/10.1016/j.jpolmod.2005.04.001

Butter, D. (2015). Syria's economy: Picking up the piece. Royal Institute of International Affairs, Middle East and North Africa Programme Research Paper. London: Chatham House (Erişim: 06.12.2017), https://www.chathamhouse.org/sites/files/chathamho use/field/field_document/20150623SyriaEconomyB utter.pdf

Campos, N. F., ve Karanasos, M. G. (2008). Growth, volatility and political instability: Non-linear timeseries evidence for Argentina, 1896-2000. Economics Letters, 100(1), 135-137. https://doi.org/10.1016/j.econlet.2007.12.013

Campos, N. F., Karanasos, M. G., ve Tan, B. (2012). Two to tangle: Financial development, political instability and economic growth in Argentina. Journal of Banking \& Finance, 36(1), 290-304. https://doi.org/10.1016/j.jbankfin.2011.07.011

Campos, N. F., ve Nugent, J. B. (2002). Who is afraid of political instability?. Journal of Development Economics, 67(1), 157-172. https://doi.org/10.1016/S0304-3878(01)00181-X

Caporale, T., ve Leirer, J. (2010). Take the money and run: Political turnover, rent-seeking and economic growth. Journal of Economic Behavior \& Organization, 76(2), 406-412. https://doi.org/10.1016/j.jebo.2010.07.005

Çelik, S., Deniz, P., ve Eken, S. (2008). Eşbütünleşme analiziyle Türkiye için ikiz açıklar hipotezi: 19962006. 2. Ulusal İktisat Kongresi.

Çelikpala, M. (2014). Enerji güvenliği: NATO’nun yeni tehdit algısı. Uluslararası Ilisşkiler, 10(40), 75-99.

Chen, B., ve Feng, Y. (1996). Some political determinants of economic growth: Theory and empirical implications. European Journal of Political Economy, 12(4), 609-627. https://doi.org/10.1016/S0176-2680(96)00019-5

Fosu, A. (2001). Political instability and economic growth in developing economies: some specification empirics. Economics Letters, 70(2), 289-294.
https://doi.org/10.1016/S0165-1765(00)00357-8

Gurgul, H., ve Lach, Ł. (2013). Political instability and economic growth: Evidence from two decades of transition in CEE. Communist and Post-Communist Studies, 46(2), 189-202. https://doi.org/10.1016/j.postcomstud.2013.03.008

Hotunluoğlu, H., ve Özçağ, M. (2012). İnternet kullanımının vergi gelirlerine etkisi: OECD üyesi ülkeler için ampirik bir analiz. Maliye Dergisi, 163, 354-366.

Im, K. S., Pesaran, M. H., ve Shin, Y. (2003). Testing for unit roots in heterogeneous panels. Journal of Econometrics, 115(1), 53-74. https://doi.org/10.1016/S0304-4076(03)00092-7

IEA. (2017). What is energy security?. (Erişim: 30.05.2017),

https://www.iea.org/topics/energysecurity/subtopics/ whatisenergysecurity

International Monetary Fund. IMF Data. (Erişim: 02.11.2017), http://data.imf.org

Jong-A-Pin, R. (2009). On the measurement of political instability and its impact on economic growth. European Journal of Political Economy, 25(1), 1529. https://doi.org/10.1016/j.ejpoleco.2008.09.010

Kao, C. (1999). Spurious regression and residual-based tests for cointegration in panel data. Journal of Econometrics, 90(1), 1-44. https://doi.org/10.1016/S0304-4076(98)00023-2

Karabulut, B. (2017). Enerji güvenliğine küresel ölçekte bir bakış. Savunma Bilimleri Dergisi, 15(1), 31-54.

Karagöl, E., Erbaykal, E., ve Ertuğrul, H. M. (2007). Türkiye de ekonomik büyüme ile elektrik tüketimi ilişkisi: Sınır testi yaklaşımı. Doğuş Üniversitesi Dergisi, 1(8), 72-80. https://doi.org/10.31671/dogus.2019.243

Kartal, G. (2018). Orta Doğu ülkelerinde politik istikrarsızlı, enerji güvenliği ve ekonomik büyüme ilişkisi. Doktora Tezi. Nevşehir: Nevşehir Hacı Bektaş Veli Üniversitesi.

Kartal, G. (2020). Politik istikrarsizlik ve enerji güvenliği ekseninde Orta Doğu ekonomileri. İstanbul: Hiperyayın.

Kartal, G., ve Öztürk, S. (2018). Politik istikrarsızlık, uluslararası göç hareketleri ve ekonomik etkileri: Türkiye ve güney komşuları (İran, Irak ve Suriye) üzerine bir inceleme. Içinde E. Özensel, G. Bozbaş, F. Kaleci, ve M. N. Salur (Ed.), Ortadoğuda Göç Hareketleri ve Değişen Dinamikler. 180-199, Konya: Aybil Yayınevi.

Klomp, J., ve de Haan, J. (2009). Political institutions and economic volatility. European Journal of Political Economy, 25(3), 311-326. https://doi.org/10.1016/j.ejpoleco.2009.02.006

Knutsen, C. H. (2013). Democracy, state capacity, and economic growth. World Development, 43, 1-18. https://doi.org/10.1016/j.worlddev.2012.10.014 
Kök, R., ve Şimşek, N. (2006). Endüstri-içi dış ticaret, patentler ve uluslararası teknolojik yayılma. Türkiye Ekonomi Kurumu Uluslararası Ekonomi Konferansi. 11-13 Eylül 2006, Ankara.

Kruyt, B., van Vuuren, D. P., de Vries, H. J. M., ve Groenenberg, H. (2009). Indicators for energy security. Energy Policy, 37(6), 2166-2181. https://doi.org/10.1016/j.enpol.2009.02.006

Le, T. H., ve Nguyen, C. P. (2019). Is energy security a driver for economic growth? Evidence from a global sample. Energy Policy, 129, 436-451. https://doi.org/10.1016/j.enpol.2019.02.038

Levin, A., Lin, C.-F., ve James Chu, C.-S. (2002). Unit root tests in panel data: asymptotic and finite-sample properties. Journal of Econometrics, 108(1), 1-24. https://doi.org/10.1016/S0304-4076(01)00098-7

Man, G. (2016). Political competition and growth in global perspective: Evidence from panel data. Journal of Applied Economics, 19(2), 363-382. https://doi.org/10.1016/S1514-0326(16)30015-0

Martin, P., ve Ann Rogers, C. (2000). Long-term growth and short-term economic instability. European Economic Review, 44(2), 359-381. https://doi.org/10.1016/S0014-2921(98)00073-7

Menegaki, A. N., ve Ozturk, I. (2013). Growth and energy nexus in Europe revisited: Evidence from a fixed effects political economy model. Energy Policy, 61, 881-887.

https://doi.org/10.1016/j.enpol.2013.06.076

Miljkovic, D., ve Rimal, A. (2008). The impact of socioeconomic factors on political instability: A crosscountry analysis. The Journal of Socio-Economics, $37(6)$, https://doi.org/10.1016/j.socec.2008.04.007

Morshed, H. A. S. (2010). A panel cointegration analysis of the Euro area money demand. Master Thesis. Lund: Lund University.

Nazlığlu, Ş. (2010). Makro iktisat politikalarının tarım sektörü üzerindeki etkileri: gelişmiş ve gelişmekte olan ülkeler için bir karşılaştırma. Doktora Tezi. Kayseri: Erciyes Üniversitesi.

Özer, M., ve Kocaman, M. (2019). A bootstrap panel granger causality analysis of relationships between political instability and macroeconomic variables. Uluslararası Ekonomi, İşletme ve Politika Dergisi, 3(2), 239-252. https://doi.org/10.29216/ueip.585261

Pedroni, P. (1999). Critical values for cointegration tests in heterogeneous panels with multiple regressors. Oxford Bulletin of Economics and Statistics, 61(s1), 653-670. https://doi.org/10.1111/1468$0084.0610 \mathrm{~s} 1653$

Pedroni, P. (2000). Fully modified ols for heterogeneous cointegrated panels. Advances in econometrics, 15, 93-130. https://web.williams.edu/Economics/wp/pedroniaie. pdf

Pedroni, P. (2004). Panel cointegration: Asymptotic and finite sample properties of pooled time series tests with an application to the PPP hypothesis. Econometric Theory, 20(03). https://doi.org/10.1017/S0266466604203073

Rachdi, H., ve Saidi, H. (2015). Democracy and economic growth: Evidence in MENA countries. Procedia Social and Behavioral Sciences, 191, 616-621. https://doi.org/10.1016/j.sbspro.2015.04.644

Radu, M. (2015). Political Stability - a condition for sustainable growth in Romania? Procedia Economics and Finance, 30, 751-757. https://doi.org/10.1016/S2212-5671(15)01324-6

Saidi, K., Rahman, M. M., ve Amamri, M. (2017). The causal nexus between economic growth and energy consumption: New evidence from global panel of 53 countries. Sustainable Cities and Society, 33, 45-56. https://doi.org/10.1016/j.scs.2017.05.013

Şanlısoy, S. (2020). Türkiye'de politik istikrarsızlık ile ekonomik büyüme ilişkisi: Bir nedensellik analizi. Bilig, 92, 85-114. https://doi.org/10.12995/bilig.9204

Şanlısoy, S., ve Çetin, M. (2017). Türkiye ekonomisinde politik istikrarsızlık-makro ekonomik performans ilişkisi. Dokuz Eylul Universitesi Iktisadi ve Idari Bilimler Dergisi, 32(2), 207-237. https://doi.org/10.24988/deuiibf.2017322606

Şanlısoy, S., ve Kök, R. (2016). Politik istikrarsızlık ekonomik büyüme ilişkisi: Türkiye örneği (19872006). Dokuz Eylül Üniversitesi İktisadi İdari Bilimler Fakültesi Dergisi, 25(1). https://dergipark.org.tr/tr/pub/deuiibfd/issue/22735/2 42657

Sen, K. (2013). The political dynamics of economic growth. World Development, 47, 71-86. https://doi.org/10.1016/j.worlddev.2013.02.015

Seshaiah, V. S., ve Tripathy, T. (2018). GDP purchasing power parity per capita and its determinants: A panel data analysis for BRICS. Theoretical Economics Letters, $\quad$ 08(03), 575-571. https://doi.org/10.4236/tel.2018.83040

Stavytskyy, A., Kharlamova, G., Giedraitis, V., ve Šumskis, V. (2018). Estimating the interrelation between energy security and macroeconomic factors in European countries. Journal of International Studies, 11(3), 217-238. https://doi.org/10.14254/2071-8330.2018/11-3/18

Sweidan, O. D. (2016). Political instability and economic growth: Evidence from Jordan. Review of Middle East Economics and Finance, 12(3). https://doi.org/10.1515/rmeef-2015-0025

Tabassam, A. H., Hashmi, S. H., ve Rehman, F. U. (2016). Nexus between political instability and economic growth in Pakistan. Procedia - Social and Behavioral Sciences, 230, 325-334. https://doi.org/10.1016/j.sbspro.2016.09.041

Tang, C. F., ve Abosedra, S. (2014). The impacts of tourism, energy consumption and political instability on economic growth in the MENA countries. Energy 
Policy, 68, 458-464. Yalçınkaya, Ö., ve Kaya, V. (2017). Politik https://doi.org/10.1016/j.enpol.2014.01.004

Tarı, R. (2011). Ekonometri. Umuttepe Yayınları.

Uçan, O. (2011). Açık ekonomilerde döviz kuru dinamikleri: Türkiye örneği. Doktora Tezi. Adana: Çukurova Üniversitesi.

UNCTAD. UNCTADstat. (Erişim:06.12.2017) http://unctadstat.unctad.org/EN

Voser, P. (2012). Energy: The Oxygen of the Economy. World Economic Forum Energy for Economic Growth Energy Vision Update 2012. (Erişim: 31.05.2017), http://www3.weforum.org/docs/WEF_EN_EnergyE conomicGrowth_IndustryAgenda_2012.pdf

World Bank. World Development Indicators Database. (Erişim: 14.01.2017), https://datacatalog.worldbank.org/dataset/worlddevelopment-indicators istikrarın/istikrarsızlığın ekonomik büyüme üzerindeki etkileri: Dünyanın en büyük ilk yirmi ekonomisi üzerinde bir uygulama (1996-2015). International Journal of Management Economics and Business, 13(2), 277-298. https://doi.org/10.17130/ijmeb.2017228684

Yang, B. (2011). Political democratization, economic liberalization, and growth volatility. Journal of Comparative Economics, 39(2), 245-259. https://doi.org/10.1016/j.jce.2010.08.001

Younis, M., Lin, X. X., Sharahili, Y., ve Selvarathi, S. (2008). Political stability and economic growth in Asia. American Journal of Applied Sciences, 5(3), 203-208.

https://doi.org/10.3844/ajassp.2008.203.208

Zouhaier, H., ve Kefi, M. K. (2012). Interaction between political instability and investment. Journal of Economics and International Finance, 4(2), 49-54. https://doi.org/10.5897/JEIF11.127. 